SNEŽANA NIKOLIĆ

Institute of Archaeology

Belgrade, Serbia

E-mail: snenik@gmail.com

MILICA MARJANOVIĆ

Institute of Archaeology

Belgrade, Serbia

E-mail:milicamitic87@yahoo.com

GORAN STOJIĆ

Centre for New Technologies

Viminacium - Belgrade, Serbia

E-mail: stojicgoran@gmail.com
Received: November $15^{\text {th }} 2021$

Accepted: November $20^{\text {th }} 2021$

Original research article

904:726.8"652"(497.11)

902.2(497.11)"2016/2020"

COBISS.SR-ID 55378697

https://doi.org/10.18485/arhe_apn.2021.17.2

\title{
THE NECROPOLIS ALONG THE NORTH-WESTERN CORNER OF THE LEGIONARY FORTRESS IN VIMINACIUM
}

\begin{abstract}
During more recent archaeological research in the area of the legionary fort of the Legio VII Claudia in Viminacium, a part of the defensive ditch along the north-western part of the camp was also explored. Several archaeological units were discovered in this area, among others, a smaller necropolis with skeletal burials as well. This necropolis consists of 36 graves, mostly with brick and tegulae constructions, and also several freely buried individuals. On the basis of the stratigraphy and the few find of coins, this necropolis was dated to the second half of the 4th century. It is interesting to note that the most numerous graves at the necropolis are those of new-borns and children, with only a few adult individuals registered.
\end{abstract}

KEYWORDS: NECROPOLIS, GRAVES, LATE ANTIQUITY, VIMINACIUM, LEGIONARY FORT, DEFENSIVE DITCH.

Archaeological excavations of the military fort at Viminacium, on a small scale and with long interruptions, have been performed from the end of the $19^{\text {th }}$ century, and after an intermission of several decades, continued in 2002, when the northern gate of the fortress (porta praetoria) was mostly discovered. ${ }^{1}$ Continuous research, performed since 2016, was focused on the north-western part of the fort, up until 2020 (fig. 1). For the most part, works were performed on the discovered ramparts and towers,

1 On the history of previous research, cf. Mrđić 2009: 9-16. as well as the defensive ditch, stretching along the outer side of the ramparts, and the inner part of the fortress was comprehended only with a smaller part. ${ }^{2}$ During these excavations, the research of the northern gate was finished, and the western gate (porta principalis sinistra) was also discovered, with towers, passages and drainage channels, and also a smaller part of the viae principalis, as well as

2 Results of the research of the north-western part of the fort were published in journals of the Institute of Archaeology: Nikolić et al. 2019: 125-134; Nikolić et al. 2020: 143-155; Bogdanović et al. 2020: 157-170. 


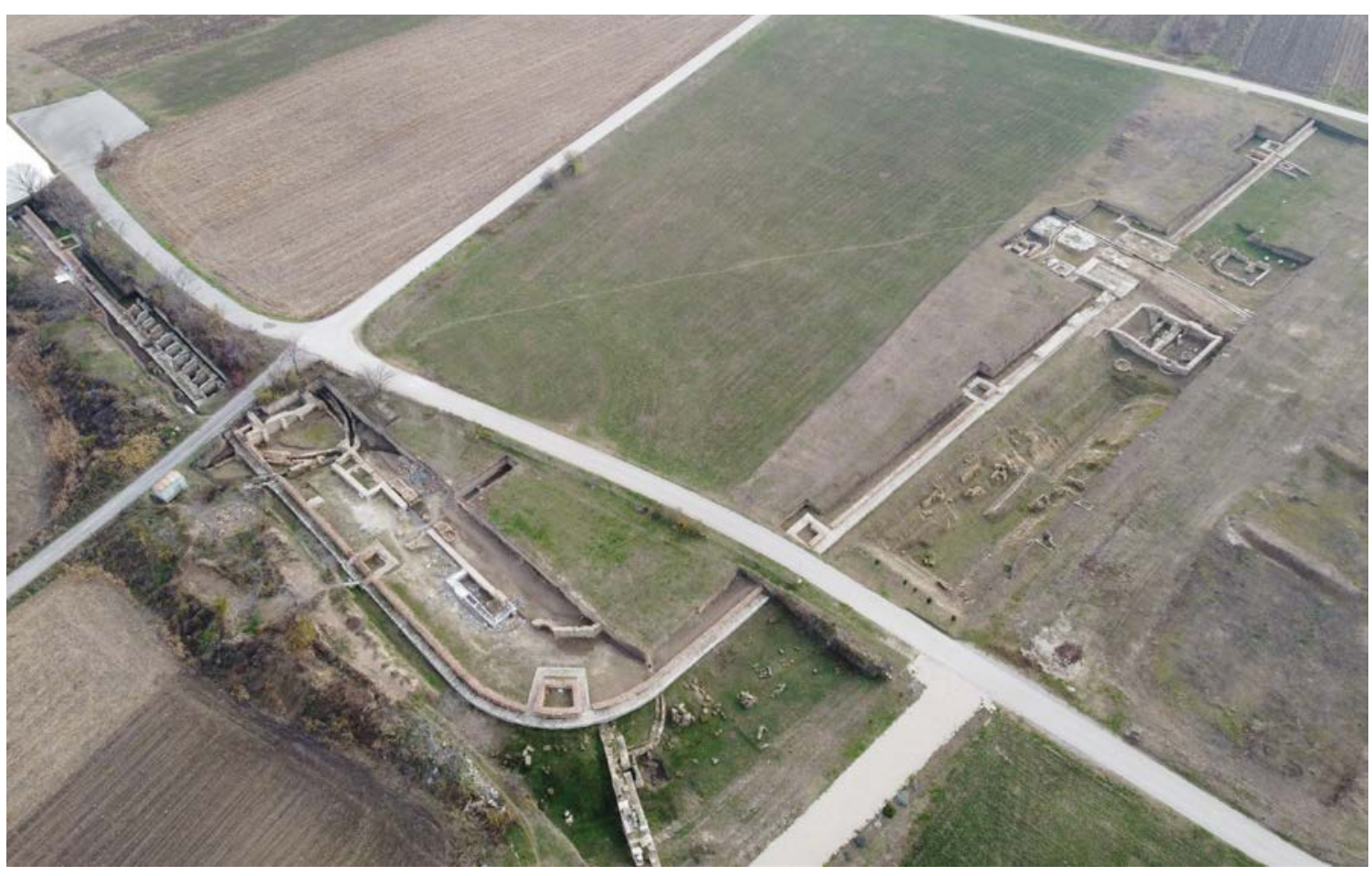

Fig. 1 North-western part of the military camp, shot from the drone (photo documentation of the Institute of Archaeology)

the communication that stretched from the street, i.e. the gate, to the west - the city. Parts of the western and northern rampart were also discovered, as well as the north-western corner tower and lateral towers on the ramparts. Aside from the channel within the gates, several more drainage channels were researched, through which the waste waters from the fort went to the ditch. On the basis of the stratigraphy, manner of building and numerous archaeological findings, two basic phases of the construction of the fortress were established - an older one, dated to the last decades of the 1st century, and a more recent one, dated to the $2^{\text {nd }}$ century.

As already mentioned, a defensive ditch was also discovered, which was bridged with a massive wall made of large limestone blocks, near the north-western corner of the fort. After the ditch was backfilled, that is to say, after the end of its use for defensive purposes (after the third quarter of the $3^{\text {rd }}$ century), several buildings of economic character, and also five circular ovens, were built over the ditch, in the area to the north and to the south of the communication. Various phases of building and reconstructions can be noted on those objects, which lasted through the entire 4th and into the beginning of the $5^{\text {th }}$ century.

During the research of the ramparts and the ditch, a Late Roman necropolis was also discovered, which was mostly dug in along the outer side of the western rampart and along the edges of the ditch.

$$
* * *
$$

Within the necropolis on the castrum, 36 graves have been researched, in which 37 individuals were buried. ${ }^{3}$ Those were skeletal burials of deceased individuals, mostly children. The burials were mostly performed in tombs made of bricks and tegulae, with a considerably smaller number of freely buried individuals. The grave constructions were damaged to varying degrees, and the bones of the skeletons were mostly poorly preserved and most commonly demolished. No regularities were noted in the orientation or distribution of the graves.

\footnotetext{
3 There were no skeletal remains in one grave, but there were three individuals buried in another.
} 
When observing the distribution of the graves, it is necessary to take into consideration the uneven degree of the research of the ditch. This goes for both the different research level of the ditch along the western rampart, compared to the part along the northern rampart, as well as the uneven research level of the ditch along the western rampart. Along the western rampart of the fortress, the ditch was researched to a length of ca $200 \mathrm{~m}$, where it was $16.50-17.20 \mathrm{~m}$ wide, and up to 5.80 $\mathrm{m}$ deep. The eastern edge of the ditch was at a distance ca $1.40 \mathrm{~m}$ from the more recent rampart of the fortress. The ditch was not dug through the area where the communication was, but ca $5 \mathrm{~m}$ to the north and south of it. ${ }^{4}$ It was precisely in the area to the north and to the south of the communication that the ditch was excavated completely to a length of ca $60 \mathrm{~m}$, and a smaller segment of the ditch was researched to the bottom near the north-western corner of the fortress as well. The remaining, largest part of the ditch, was excavated to various depths, and it should be noted that to the south of the communication, in one segment, its western edge has not yet been discovered.

Along the northern rampart of the fort, the ditch was researched to a considerably smaller extent in the section from the corner tower to the northern gate, compared to the section on the western side. Even though the rampart was discovered to a length of $180 \mathrm{~m}$, the southern side and the bottom of the ditch have been researched to a length of less than $20 \mathrm{~m}$, while only the southern edge has (mostly) been researched in the remaining part.

With the exception of one grave (G-20), ${ }^{5}$ located along the northern rampart of the more recent fortress, the graves were mostly distributed along the western rampart (fig. 2).

Most of the graves (26) along the western rampart were located between the rampart and

4 A small part of the ditch, at a length of ca $5 \mathrm{~m}$, is located under the modern road.

5 Aside from this grave, the poorly preserved skeletal remains of two more individuals, a new-born and a child in the first months of life, were registered along the northern rampart, whose graves have not been documented yet. the ditch, at a distance of $1.25 \mathrm{~m}$ from the face of the rampart. The northernmost grave was dug in along the eastern end of a massive wall, which was bridging the ditch near the north-western corner, in the vicinity of the corner tower. Further to the south, graves were distributed individually, or in groups, at different distances. Six graves were discovered in the infill of the ditch, with only one of them in its central part, and this was also the grave that was dug in deepest in this necropolis. Above the western side of the ditch, three graves were discovered, one of them dug in to the west of the edge of the ditch, that is to say, outside the edges of the ditch. All graves on the western side were located to the north of the communication that led from the fortress to the city. The reason for that could potentially be the poor research level of the western side of the ditch in the southern trenches.

The largest number of graves (29) has constructions in the shape of rectangular tombs made of bricks and tegulae of different dimensions, ${ }^{6}$ that are laid sideways. The outer sides of the tombs were occasionally reinforced/fastened with smaller fragments of tegulae and bricks or small pieces of schist or limestone. Most of the constructions had a floor in the form of horizontally laid whole or fragmented bricks and tegulae, while putting schist at the bottom of graves represents an exception. In several cases, the deceased were laid directly onto the ground, i.e., the construction had no floor. The covers of the tombs were usually formed of horizontally placed bricks and tegulae, more rarely in the form of a double pitched roof, and in only one case, a fragment of a limestone block was used as a part of the cover. Aside from these constructions, seven freely dug graves were also registered. Graves from this necropolis have different orientations and no regular pattern was noted in their distribution. It can be noted that there are no cases of one grave damaging another, they are often clustered and they were all dug into

6 Dimensions of the bricks are between $38 \times 29 \times 4 \mathrm{~cm}$ (smallest) and $42 \times 31 \times 4 \mathrm{~cm}$ (largest), while the dimensions of tegulae vary between $48 \times 36 \times 3 \mathrm{~cm}$ (smallest) and $56 \times 42 \times 5 \mathrm{~cm}$ (largest). 


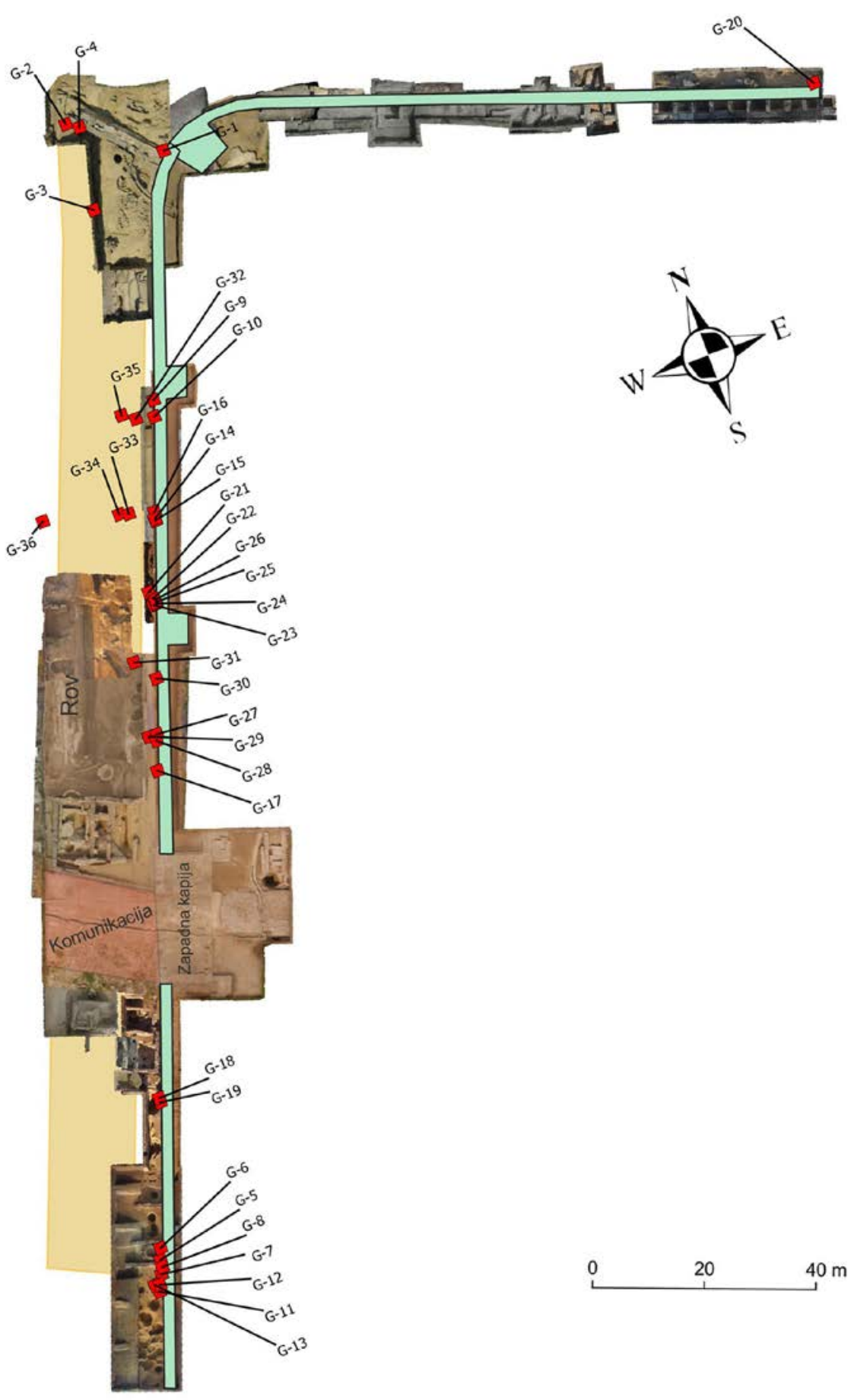

Fig. 2 Distribution of the graves along the rampart and within the camp (Ž. Jovanović, I. Marjanović)

a more recent Late Roman horizon.

As was mentioned in the introduction, 36 graves were discovered and processed in a catalogue, in which 37 individuals were buried. ${ }^{7}$ There

7 Data on the sex and age of individuals was taken from were no skeletal remains in one grave (G-3), and there were three individuals buried in another (Ganthropological reports of Dr Ilija Mikić and Dr Nataša Šarkić. We would like to take this occasion to thank Dr Ilija Mikić for additional help and useful information. 
33). Almost half are graves with new-borns buried in them (18 graves), six have babies in the first months - up to six months of age buried in them, and eight graves contain children of different ages (Table 1).

Adults were found in only five graves, among which there are three female individuals, one aged ca 20, and another being the oldest person buried in this necropolis, aged ca 45 ; it was not possible to determine the age of the third female individual. The only male individual buried in this necropolis was aged between 20 and 25, and one individual remains with undetermined sex.

A number of graves were partially demolished, possibly also raided and, consequently, aside from the damage to the constructions themselves, the skeletal remains were also disturbed. Also, we should bear in mind the poor preservation level of the skeletal remains in most graves. Even though the position of certain skeletons cannot be determined with precision, or at all, because of the damage or poor preservation level, it was determined that most individuals were buried in a supine position, with arms extended along the side of the body or, more rarely, with hands placed on the pelvis/stomach.

An extremely small number of grave goods can be noted at the researched necropolis; most graves had no goods discovered, even those that were not damaged or raided. Of the total number of graves (36), only 5 graves had any goods (13.89\%), with 8 find discovered in them (fig. 3/1-5). In a grave of a baby aged up to six months (G-2), four beads were found - one made of bone and three made of glass, as well as a thin bronze hoop (bracelet) with a pendant - bell. There was one find in each of three graves: in a grave of a new-born (G-11) a part of a bronze bracelet was found, and in the grave of a child that was between one and two years old (G12) there was a bronze coin of Valentinian (364$365)$. On the right hand of a girl aged between seven and eleven years old (G-23), there was a bronze ring. Two pieces of poorly preserved coins from the 4th century (one of which was dated to the sixth decade of the 4th century) and one polyhedral bead of green glass represented the goods from the grave of a girl aged ca 20 (G-29).

All the examples of coins are dated to the 4th century; one is insufficiently legible, one is roughly dated to the sixth decade of the century, while one is a bronze coin of Valentinian (364-365). Although few in numbers, the find of coins chronologically determine this necropolis to the second half of the $4^{\text {th }}$ century, which coincides with the dating obtained on the basis of the stratigraphy, as well as other find, most prominently ceramic

\begin{tabular}{|c|c|c|}
\hline AGE & NUMBER & $\begin{array}{c}\text { PERCENTAGE OF } \\
\text { TOTAL }\end{array}$ \\
\hline New-borns & 18 & $48.65 \%$ \\
\hline Babies in the first months of life (up to 6 months) & 6 & $16.22 \%$ \\
\hline Children aged 1-2 & 2 & $5.41 \%$ \\
\hline Children aged 3-4 & 1 & $2.70 \%$ \\
\hline Children aged 5-9 & 1 & $2.70 \%$ \\
\hline Children aged 7-13 & 3 & $8.11 \%$ \\
\hline Children of undetermined age & 1 & $2.70 \%$ \\
\hline Adult individuals & 5 & $13.51 \%$ \\
\hline
\end{tabular}

Table 1 


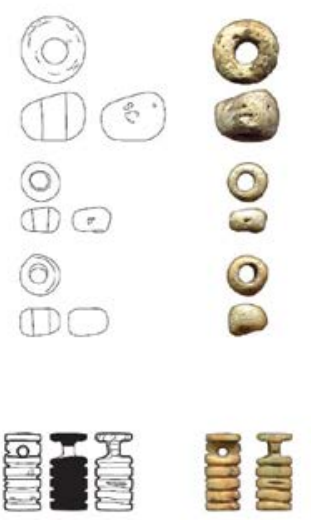

1.

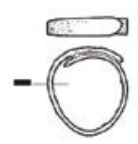

4.
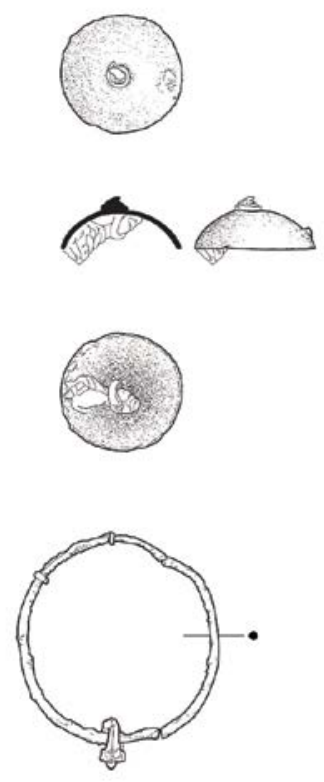

2.
3.

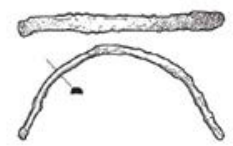

5.

Fig. 3 Findings from the graves: 1. four beads - one made of bone and three made of glass; 2. bronze hoop (bracelet) with a pendant - bell; 3. part of a bronze bracelet; 4. bronze ring; 5. polyhedral glass bead (drawn by A. Subotić)

vessels and lamps, discovered in the layers into which the graves were dug. The remaining few find from graves are, unfortunately, not chronologically sensitive.

In the Roman period, beads were most commonly an integral part of bracelets or necklaces, and they were made from diverse materials, in various shapes and sizes. Most types of beads are not chronologically sensitive, and they occur in the wider territory of the Empire in the period from the 1st to the 4th century, hence, they are usually dated on the basis of the context (Riha, 1990: 77). This was also the case with the types discovered in graves from this necropolis. Ring-shaped and spherical beads, as well as elongated beads with a hexagonal cross-section are common on Roman sites throughout the Empire. They were most commonly made of glass, and more rarely from other materials - stone, ceramics, bronze or bone. Polyhedral beads with a hexagonal cross-section are especially common in the Late Antiquity period (Guido, 1978: 96-97; Riha, 1990: 85, 89). An ex- ception is the bone bead, in the form of a smaller pendant, in a cylindrical shape, with horizontal ribs and a perforation on one of the narrower sides. No suitable analogies have been found for this find.

During the Roman period, bells were made of metals, most commonly iron or bronze, and they appear in various dimensions. They had multiple functions, depending on their size and the context in which they were found (Eckardt and Williams, 2018: 180). The discovered example of the bell on the bracelet is shallow, and hemispherical in shape. There is a perforation at the top, through which a wire was threaded, with a hanging loop, by which the bell is fastened to a thinner bronze bracelet/hoop. The bell is made of bronze, and there is an iron clapper inside, fused to the waist of the bell by corrosion. Hemispherical bells of smaller dimensions occur as early as the Flavian period, but they were used up until the 3rd and the 4th century, hence, it can be said that this type, with its numerous variations, is not chronologically sensitive (Eckardt and Williams, 2018: 185). 
The bracelet on which the bell hung is in the shape of a thinner hoop made of bronze wire, with a circular cross-section.

One of the typical find which were used in the Roman period as objects with a protective-apotropaic character, were precisely bells. They were usually examples of smaller dimensions, and they are often found in funerary contexts and in combination with other prophylactic objects (Dasen, 2003: 287; Eckardt and Williams, 2018: 197). Bells were most commonly fastened to a thinner hoop and placed on the wrist, or they represented a part of a necklace, along with other objects with a magical-apotropaic character. Their ringing sound served the purpose of chasing away the evil spirits and demons and, thus, protect the deceased. Such a use of bells has been confirmed on numerous Roman sites, among others, at the necropolis of Više Grobalja in Viminacium (those were child burials, seven skeletal burials) (Dasen, 2003: 287; Milovanović, 2016: 113-114). Aside from the bells, child graves often contained other objects that had the task, through symbolism or a specific ringing sound, of chasing away the evil forces and protecting the deceased. They are found individually, or more commonly in groups and strung onto a necklace or a bracelet, and they are classified together under the Latin term crepundia (crepare - to rattle) (Milovanović, 2016: 107, 109; Данковић, Миловановић, Марјановић, 2018: 72).

The bronze ring from grave G-23 belongs to the type with a band-shaped hoop with a rectangular cross-section, with overlapping open rounded ends. This type is not chronologically sensitive, because it occurs in contexts from the 1st up to the $4^{\text {th }}$ century (Riha, 1990: 47).

The discovered fragment of a bracelet in grave G-11 was made from a bronze band with a rectangular cross-section and, unfortunately, there are no elements that could indicate a closer typological or chronological determination for this example.

Compared to the number of researched graves, the findings from the necropolis at the castrum are few. This could be because the graves of the newborns - the most numerous type in this necropolis - were treated differently from the graves of older children in the Roman and Late Roman period. Namely, the graves of stillborn children or those that died shortly after birth were usually without finds, which changed for those at the age of six months, when grave goods are most common, and their contents more diverse (Dasen, 2003: 288). Aside from this, we should not eliminate the possibility that certain graves had been raided, or that poorer ranks of the population were buried in this area.

In one case (G-17, see footnote 11), neatly placed animal bones of different types of animals were discovered on the cover of the grave. This is a unique case of grave goods in the form of animal bones in the researched necropolis. It is possible that in this case those animal bones were placed as some sort of grave goods (or perhaps it was another ritual?), since the composition, i.e., the presence of animal types does not indicate the possibility of them being an offering of a meal for the deceased, nor the remains of a funerary meal of the living.

$$
* * *
$$

The researched necropolis along the north-western corner of the military fortress confirms the previous assumption that the ditch along the ramparts no longer had a defensive role in the Late Roman period. It is certain that burials were performed here during the second half of the $4^{\text {th }}$ century, when buildings with an economic character also existed in the ditch, in the vicinity of the communication that led from the western gate of the fort to the city, in the same period. It can be noted that no grave damaged another, that they were often grouped or located on the same level, and also that they were dug into the same cultural horizon. This indicates the use of the necropolis over a limited period. Notable is the big difference in the number and arrangement of graves in front of the western rampart of the military fortress in comparison with the area in front of the northern 
rampart. One of the reasons for the big difference is certainly the different level of excavations of the area in front of the ramparts. In addition, it is noticeable that most of the graves in front of the western rampart are located in a narrow space between the rampart and the eastern edge of the defensive ditch, not wider than $1.80 \mathrm{~m}$. Based on the small number of graves discovered in the narrow space between the edge of the ditch and the northern rampart, we can assume that the northern part of necropolis was considerably smaller. It can be assumed that the skeletal remains discovered along the northern rampart were an exception, while the area to the west of the western rampart was used as a necropolis in Late Antiquity. It is evident that the area of the legionary fortress, and most prominently the defensive ditch along the fortress, did not have the same function in Late Antiquity. Therefore, we should not be surprised by the fact that this area, even though it was located in the immediate vicinity of the city (intramuros?), was repurposed and used for burials. We do not know if this necropolis extended beyond, to the west, but this can be assumed on the basis of a grave discovered to the west of the edge of the ditch (G-36).

The question is whether the burials in this necropolis could be brought into connection, in a way, with other graves researched in the nearer vicinity as well. Namely, at a distance of ca 140 $\mathrm{m}$ to the north-west of this necropolis, in the area of the amphitheatre, a necropolis was researched, created in the Late Roman period, after this building stopped being used for spectacles. Sixty-seven graves were discovered in it, ${ }^{8}$ both freely buried, and also buried in various constructions made of bricks. A large number of them were also children. ${ }^{9}$ Four graves of adult individuals, in constructions made of bricks, were also dated to the Late Roman period - the second half of the 4th century, and they were discovered to the south-

8 Several graves were destroyed during the work of mechanical excavators.

9 Results of this research have not been published. east of the amphitheatre. It has not been established if these graves represented the western border that stretched further to the east or if they were individual burials (Nikolić, Stojić 2018: 19-27).

The disproportionate presence of child burials, compared to the total number of deceased, aside from the high mortality rate of new-borns and children in this period of crisis, also remains unsolved. The discovery of this necropolis opened numerous questions, that only future research activities will be able to provide answers to. Considering the fact that no further excavations of the ditch are foreseen in the near future, nor those of the area to the west - the city, the aim of this paper is to show the results obtained through archaeological research that could serve as a basis for further research of the fortress, as well as a further interpretation of the skeletal remains. It is expected that more detailed anthropological and physical-chemical analyses of the skeletal remains would discover the cause of the high mortality rate of the new-borns buried in this necropolis, but also provide an insight into various aspects of the life of the population of Viminacium in the Late Roman period, such as its age structure, health status and nutrition. 


\section{CATALOGUE}

\section{Grave G-1 (76.80)}

Grave with a construction made of tegulae, oriented along a north-west/south-east axis. The construction, with dimensions of $0.60 \times 0.30 \mathrm{~m}$, consists of four tegulae laid sideways. The cover is also made of tegulae, while the bottom consists of a layer of yellow clayish soil. The southern side of the construction is damaged.

This was a grave of a new-born, placed on the back, in a stretched position, with the left arm extended along the body. The skeleton is mostly damaged, with the right side missing, and most of the bones dislocated. The preserved length of the skeleton is $0.40 \mathrm{~m}$.

There were no goods in the grave.
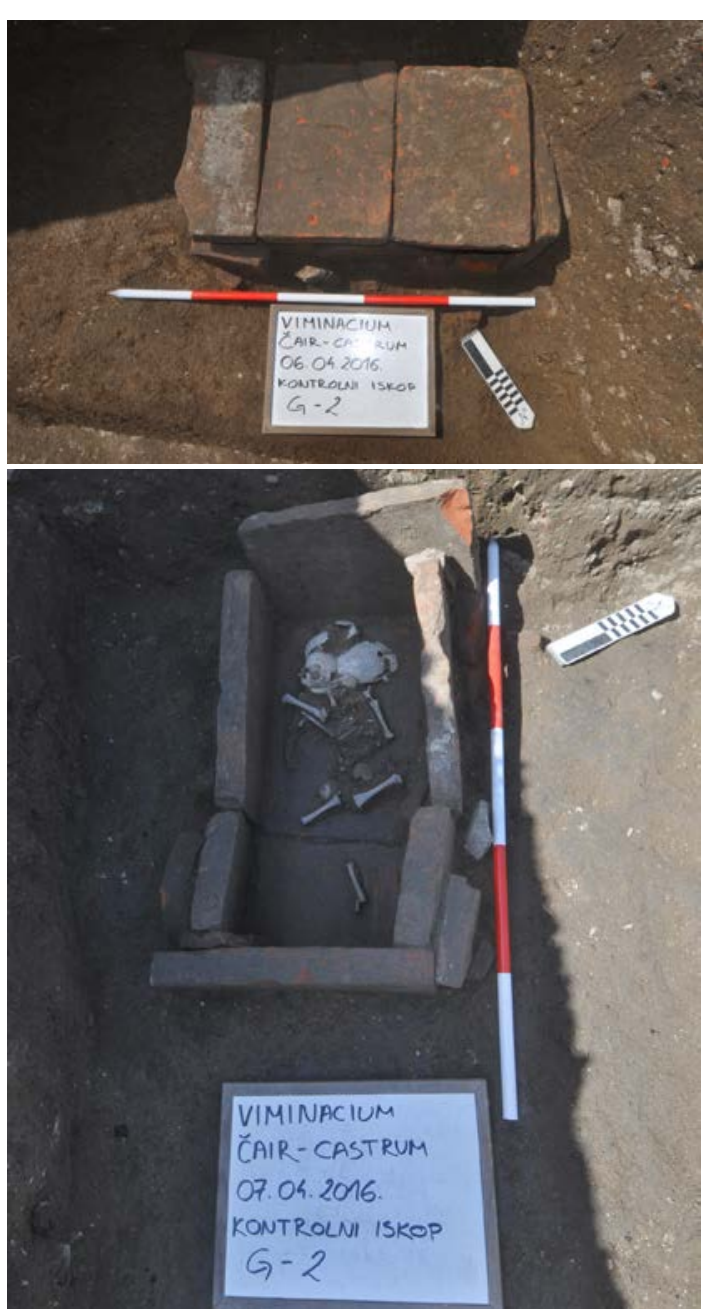
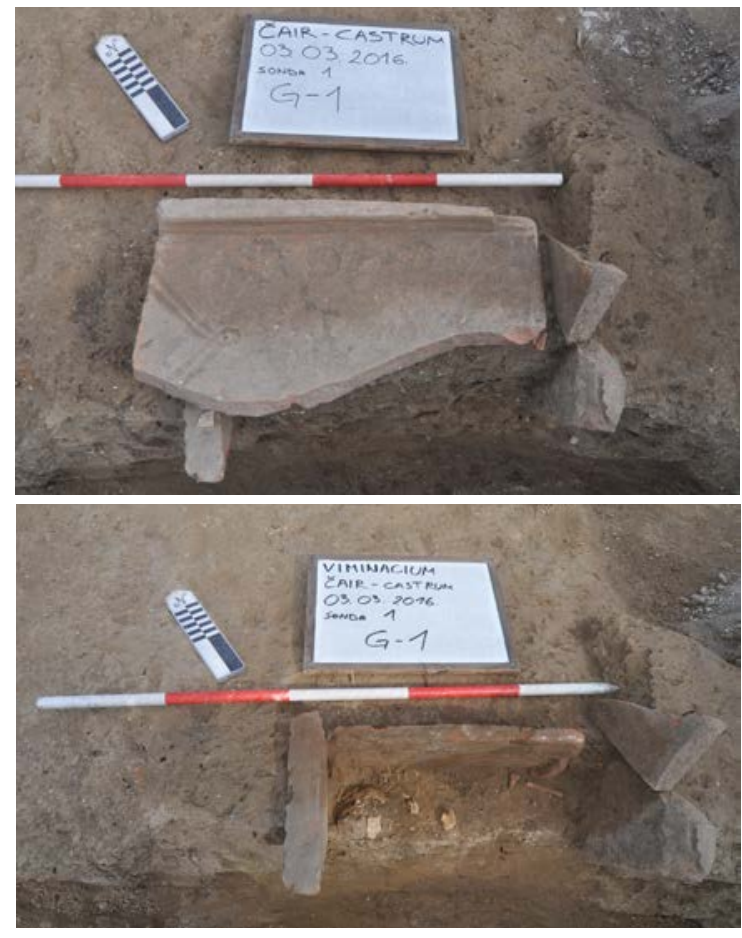

\section{Grave G-2 (76.21)}

Grave with a construction made of bricks, oriented along a west-east axis, with a slight deviation of the western side towards the north. The construction, with dimensions of $0.80 \times 0.41 \mathrm{~m}$, is formed by sideways laid bricks - one whole and a half on the longitudinal and one brick on each of the lateral sides, with longitudinal sides being reinforced with smaller fragments of bricks and schist. The bottom of the grave was paved with one whole and one half of a second brick. The cover consists of two whole and one half of a brick.

It is a grave of a child that was up to six months old, laid on the back. The fragmented skull, turned to the right, was preserved in situ, while most of the bones had been dislocated, hence, a more precise position of the deceased cannot be determined. The preserved length of the skeleton is $0.55 \mathrm{~m}$.

Four beads - one made of bone and three made of glass - were found on the chest of the deceased, along the left humerus, and along the eastern edge of the grave, near the left lower leg of the deceased, there was a thin bronze hoop with a pendant - a bell. 


\section{Grave G-3 (75.96/ 75.88)}

Grave with a construction made of bricks and tegulae, oriented along a west-east axis. The construction, with dimensions of $1.08 \times 0.40 \times 0.40$ $\mathrm{m}$, is formed by two sideways laid tegulae along the longitudinal sides, and one tegula on each of the lateral sides, with longitudinal sides being reinforced with smaller fragments of bricks and schist. One half of a brick was placed as a head rest on the eastern side of the grave. The bottom consists of two whole and one fragmented brick, while the cover consists of four damaged tegulae, which partially collapsed into the grave.

There were no skeletal remains and no grave goods in the grave.
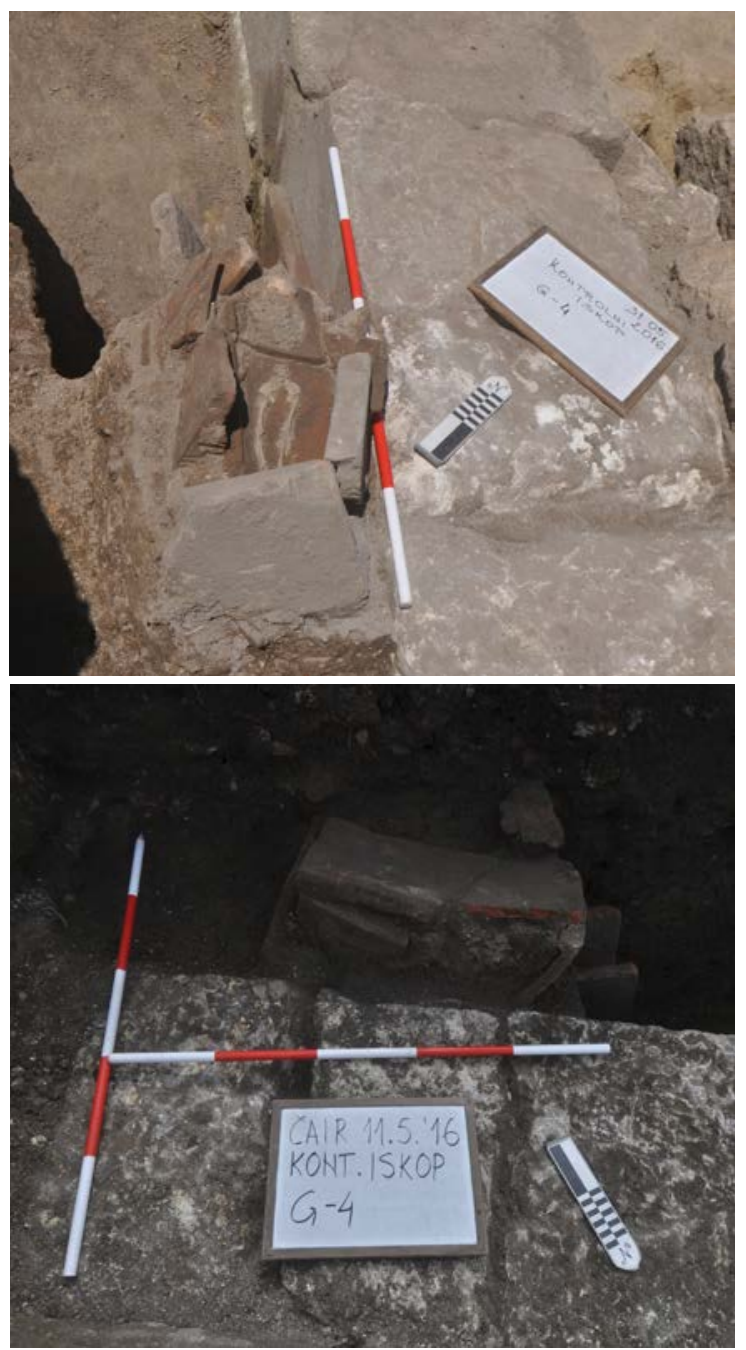
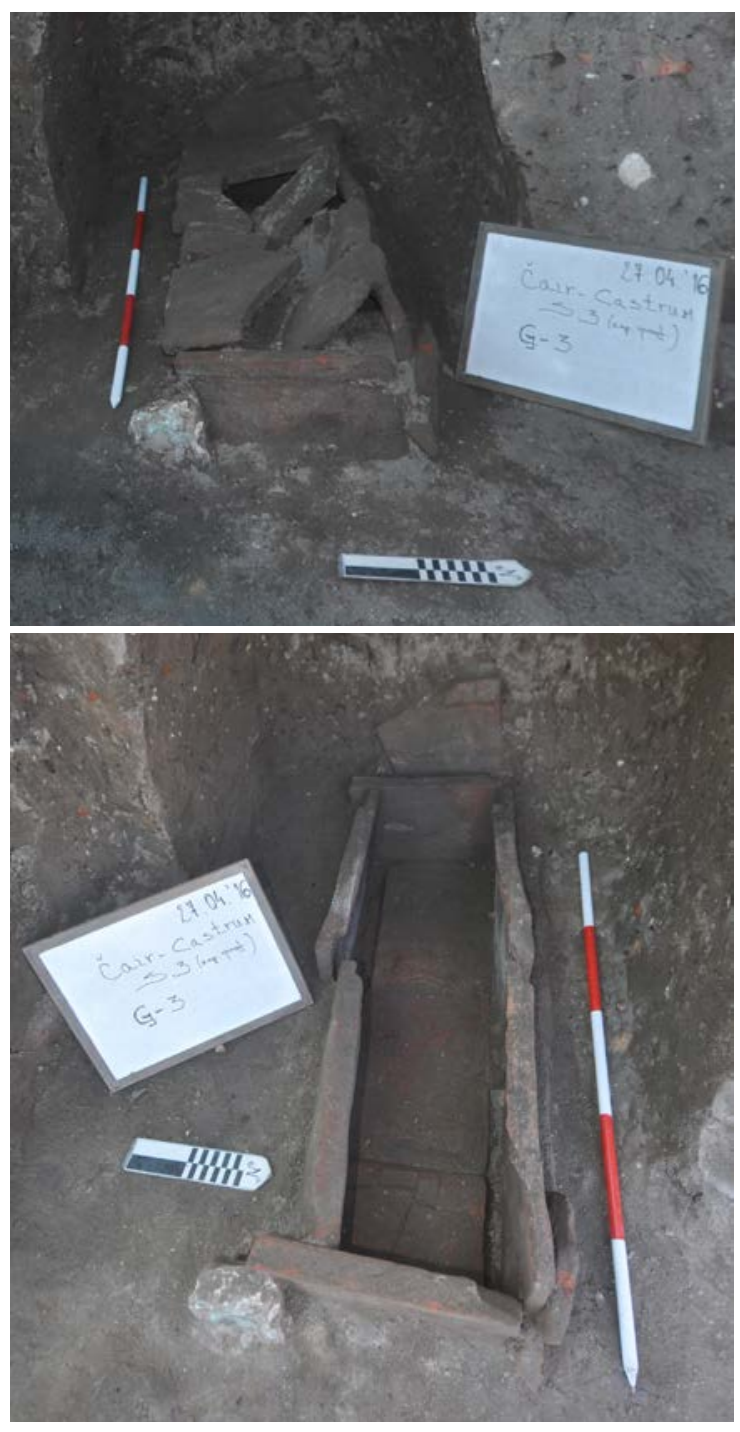

\section{Grave G-4 (76.31)}

Grave with a construction made of tegulae fragments, oriented along a north-west/south-east axis. The construction, with dimensions of $0.55 \mathrm{x}$ $0.35 / 0.25 \times 0.17 \mathrm{~m}$, is formed by fragmented tegulae laid sideways. The bottom of the grave was also made of tegulae fragments, while the cover is one broken tegula.

It is a grave of a new-born, laid on the back, with an extended right arm, and the left one slightly bent at the elbow. The preserved length of the skeleton is $0.40 \mathrm{~m}$.

There were no goods in the grave. 


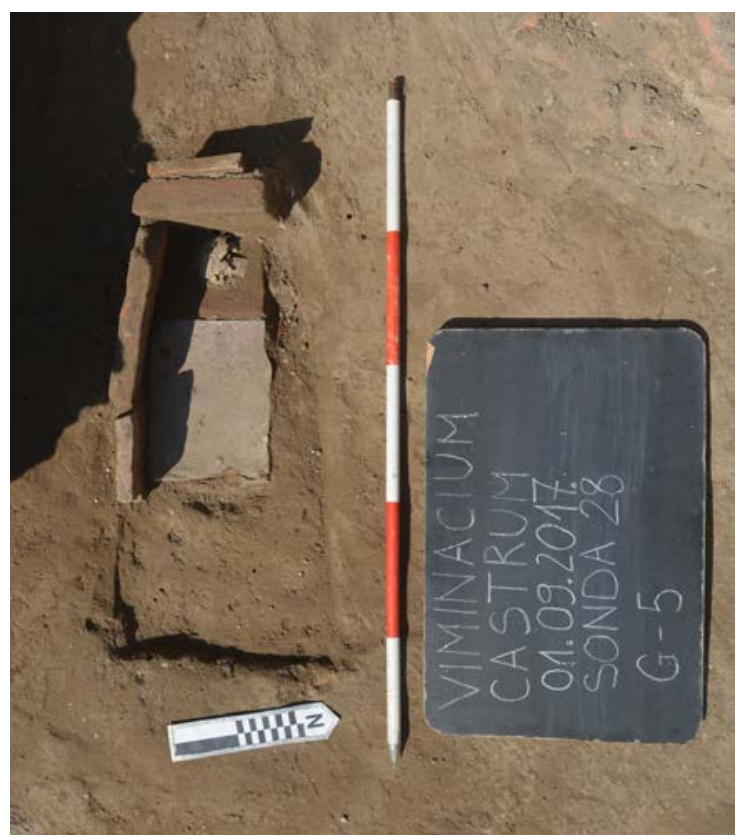

\section{Grave G-5 (78.07)}

Grave with a construction made of bricks, oriented along a west-east axis, with a slight deviation of the western part towards the north. The construction, with dimension of $0.48 \times 0.23 \mathrm{~m}$, is formed by bricks laid sideways - two on the longer side, in the south, and one on the lateral, western side. The floor of the grave consists of two whole bricks. The cover has not been discovered, and the northern and eastern part of the construction had been damaged.

It is a grave of a new-born. Considering the fact that only the skull was preserved in situ, it was not possible to determine the position of the deceased. There were no goods in the grave.

\section{Grave G-6 (78.02)}

Grave with a brick construction, oriented along a south-west/north-east axis. The construction, with dimensions of $0.60 \times 0.28 \mathrm{~m}$, is formed by sideways laid bricks - on the longitudinal sides, there was one brick placed lengthwise, and on the lateral sides, one placed across the width, among which there were pieces of schist and bricks inserted. The floor of the grave is formed by two whole bricks, while the cover was made of one brick and one fragment of a limestone block. It is a grave of a new-born, placed on the back. The skull, ribs and right arm were preserved in situ, while the other bones had been dislocated. The preserved length of the skeleton is $28 \mathrm{~cm}$. There were no goods in the grave.
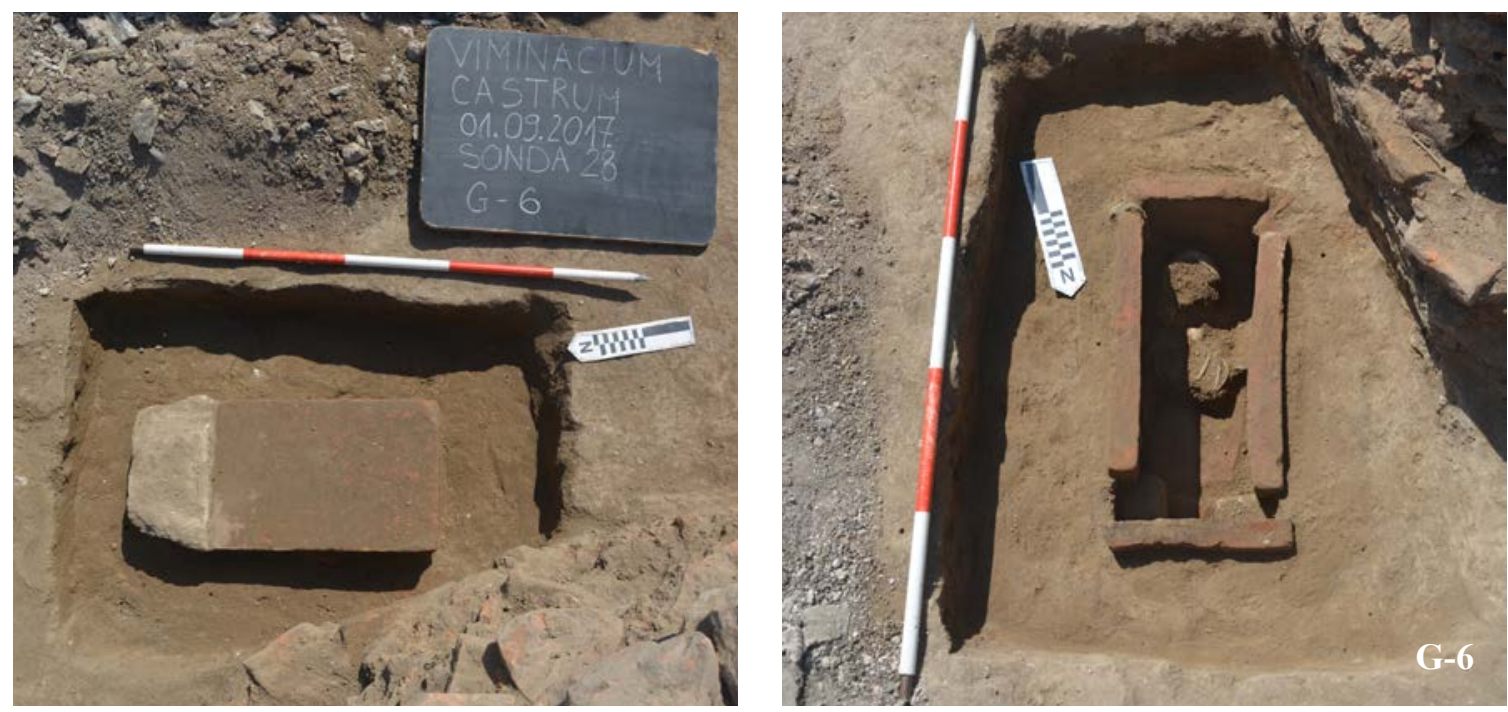


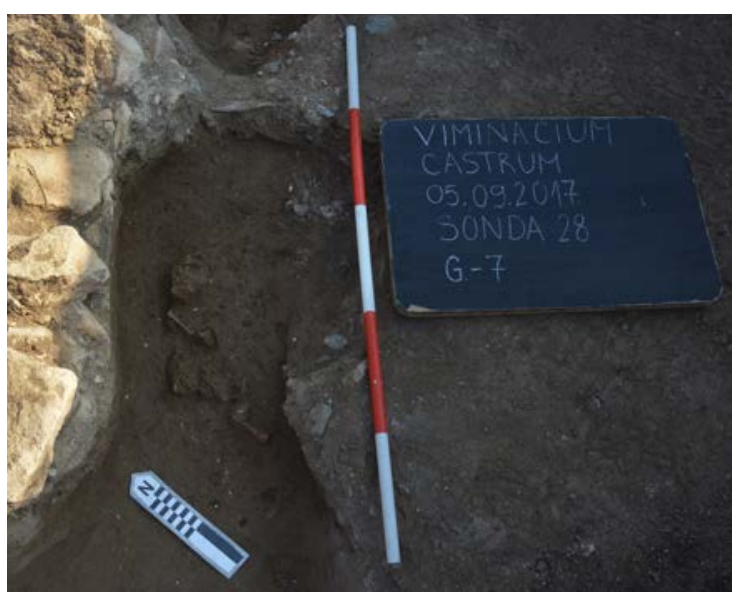

Grave G-8 (77.93)

Grave of a freely buried deceased individual, oriented along a south-north axis, with a minor deviation of the southern part towards the east.

It is a grave of a new-born, laid on the back, in a stretched position, with crossed legs. The ribs, arms, pelvis and legs were the parts of the skeleton preserved in situ, while the skull was dislocated during the excavations. The preserved length of the skeleton is $0.34 \mathrm{~m}$.

There were no goods in the grave.
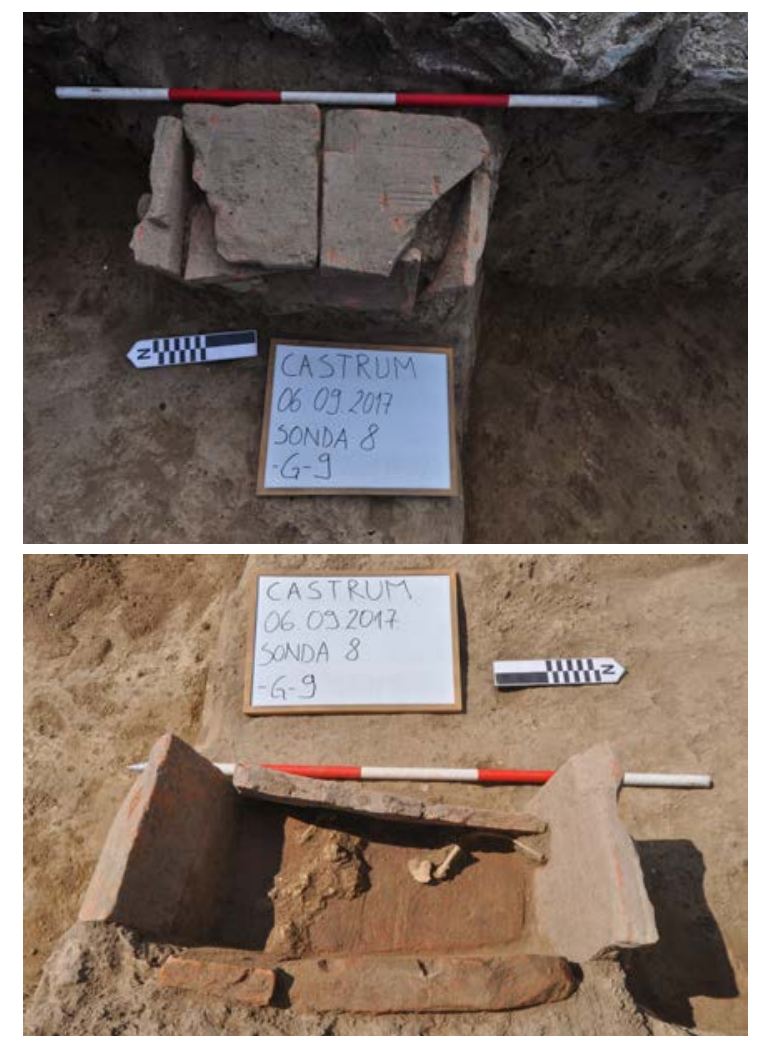

\section{Grave G-7 (77.97)}

Grave of a freely buried deceased individual, oriented along a north-east/south-west axis.

It is a grave of a child, laid on the back. Only the skull, several ribs, a part of the right arm and the right leg were preserved in situ, while the other bones had been dislocated. The preserved length of the skeleton is $0.37 \mathrm{~m}$.

There were no goods in the grave.

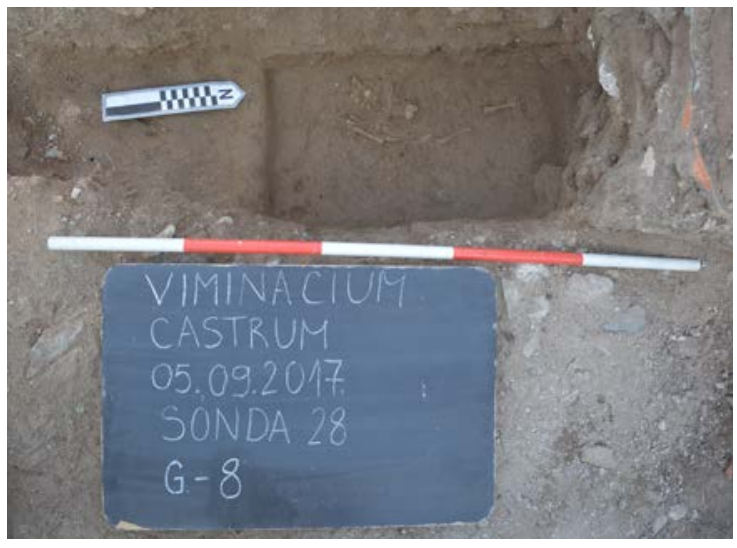

\section{Grave G-9 (77.37)}

Grave with a construction made of bricks and tegulae, approximately oriented along a south-west/ north-east axis. The construction, with dimensions of $0.55 \times 0.28 \times 0.20 \mathrm{~m}$, is formed by fragments of bricks and tegulae laid sideways. The cover consists of two fragmented tegulae, while the floor is one larger fragment of a tegula.

It is a grave of a new-born. Of all the bones, only the long bones of the right (?) leg and one half of the pelvis were preserved in situ, while the other bones had been dislocated and concentrated in the southern half of the grave. The preserved length of the skeleton is $0.20 \mathrm{~m}$.

There were no goods in the grave. 


\section{Grave G-10 (77.43)}

Grave with a construction made of tegulae, approximately oriented along a north-east/southwest axis. The construction, with dimensions of $0.55 \times 0.42 \mathrm{~m}$, is formed by fragmented tegulae laid sideways, which have been preserved only on the northern and the southern side. The cover of the grave is one whole tegula, over which a fragment of another tegula was placed, while the floor consists of a layer of earth.

It is a grave of a new-born. Of all the bones, only fragments of the calotte of the skull were preserved in situ on the northern side of the grave, and a smaller number of bones was discovered dislocated.

There were no goods in the grave.

\section{Grave G-11 (77.85)}

Grave with a construction made of bricks and tegulae, approximately oriented along a west-east axis, with a deviation of the western part towards the north. The construction, with dimensions of $0.60 \times 0.27 \times 0.10 \mathrm{~m}$, is formed by tegulae fragments laid sideways. The floor of the grave consists of four fragments of horizontally laid bricks. It is a grave of a new-born. Of all the bones, the skull, ribs, right and left hand, left side of the pel-

\section{Grave G-12 (77.39)}

Grave with a construction made of bricks and tegulae, approximately oriented along a northsouth axis, with a deviation of the northern part towards the east. The construction, with dimensions of $0.85 \times 0.25 \times 0.20 \mathrm{~m}$, is formed by bricks laid sideways on the longitudinal sides, while the construction of the narrower sides has not been discovered. The cover consists of two tegulae and one fragmented brick, and the floor is made of three fragmented bricks.

It is a grave of a child aged 1-2, laid on the back, in a stretched position, with hands placed on the stomach. Bones are well preserved, and the length of the skeleton is $0.60 \mathrm{~m}$.

A bronze coin (Valentinian) was discovered along the left side of the pelvis.
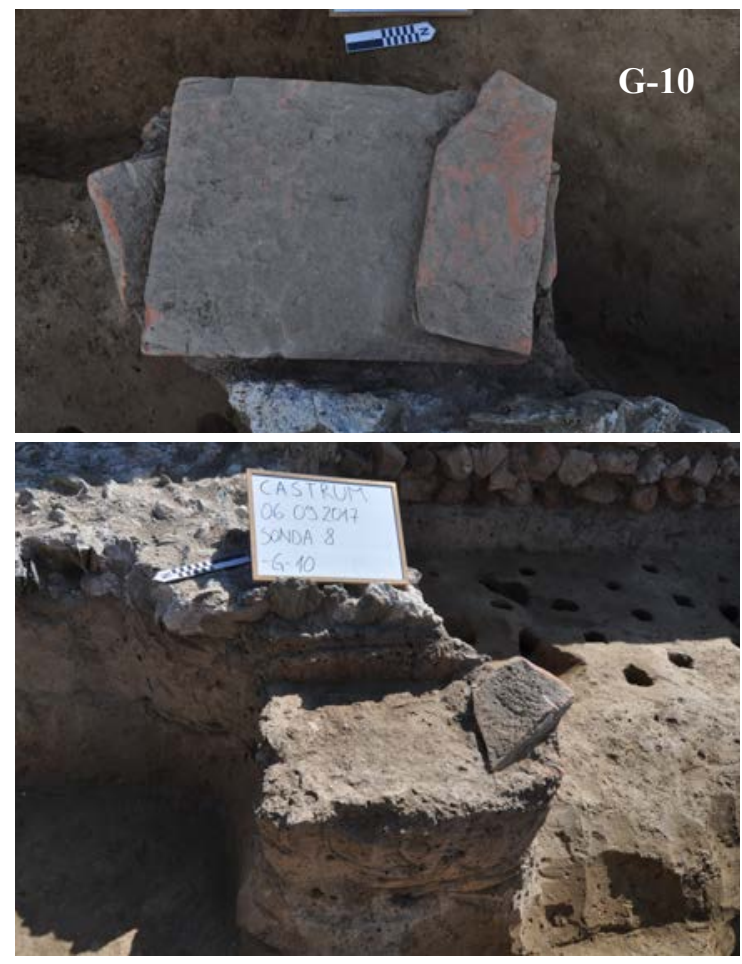

vis and left femur were preserved in situ, and a small number of bones was discovered during the emptying of the grave as well. The preserved length of the skeleton is $36 \mathrm{~cm}$.

A fragment of a bronze bracelet was discovered in the area of the chest.
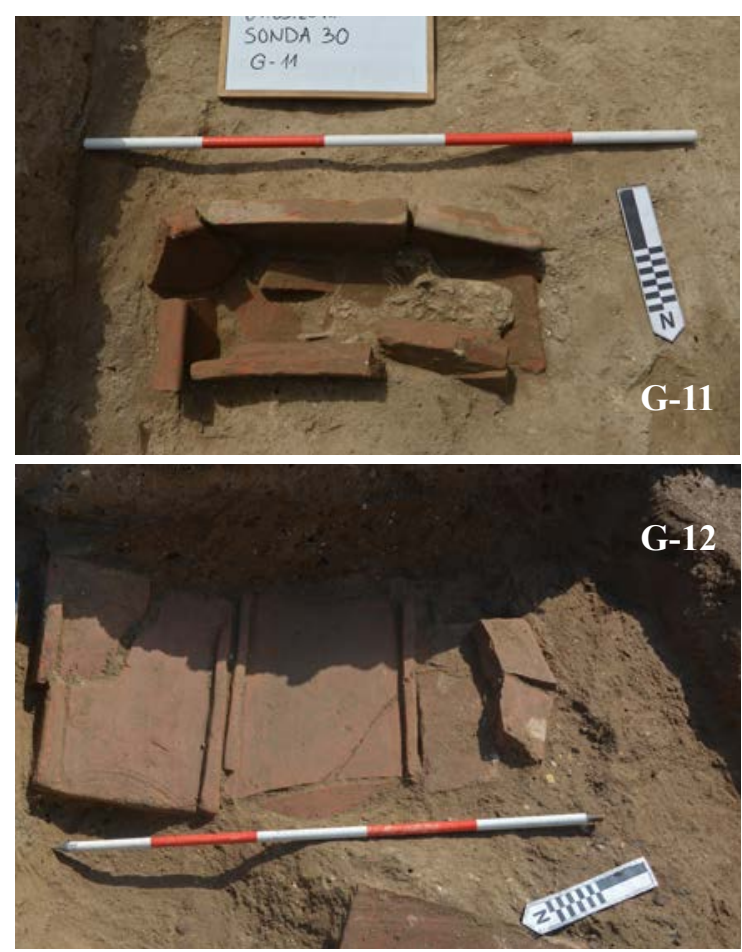


\section{Grave G-13 (77.37)}

Grave with a construction made of bricks and tegulae, approximately oriented along a north-west/ south-east axis. Only the floor was preserved from the construction, consisting of one brick ( $38 \times 29$ $\mathrm{x} 4 \mathrm{~cm}$ ), on which the body of the deceased was laid. In the layer above the deceased, a fragmented tegula was discovered, as well as brick fragments, which were not placed regularly horizontally, but which could have represented the cover of the grave.

It is a grave of a new-born, laid on the back, in a stretched position, with hands beside the body. Bones are well preserved, and the length of the skeleton is $0.45 \mathrm{~m}$.

There were no goods in the grave.

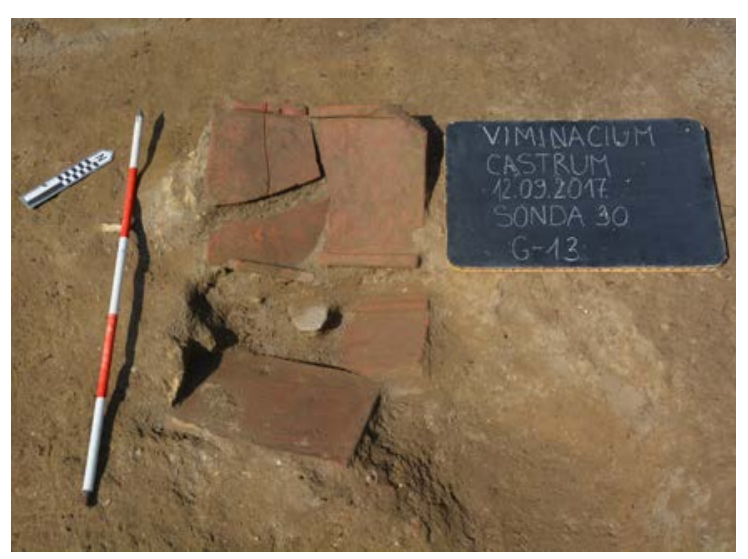

Grave G-14 (77.45)

Grave of a freely buried individual. The orientation of the grave could not be determined, because the bones were not articulated.

It is a demolished grave of a child in the first months of life, whose remains were concentrated on a surface with dimensions of $0.20 \times 0.25 \mathrm{~m}$. There were no goods in the grave.
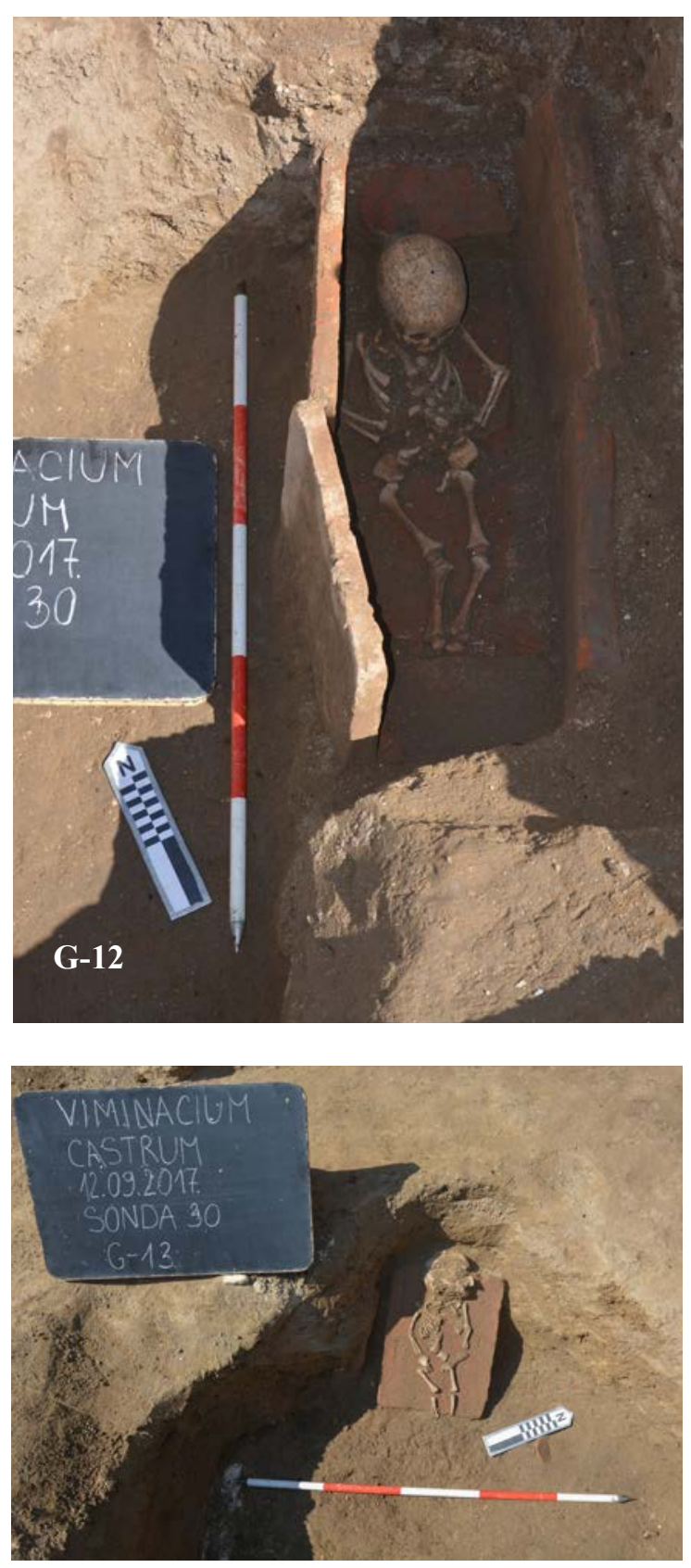

Grave G-15 (77.47)

Grave of a freely buried individual, approximately oriented along a north-east/south-west axis.

It is a demolished grave of a child aged up to six months, whose remains were concentrated on a surface with dimensions of $0.25 \times 0.25 \mathrm{~m}$. The bones of the skull, ribs, vertebrae and bones of the left forearm were preserved in situ, while the other bones had been dislocated or missing.

There were no goods in the grave. 


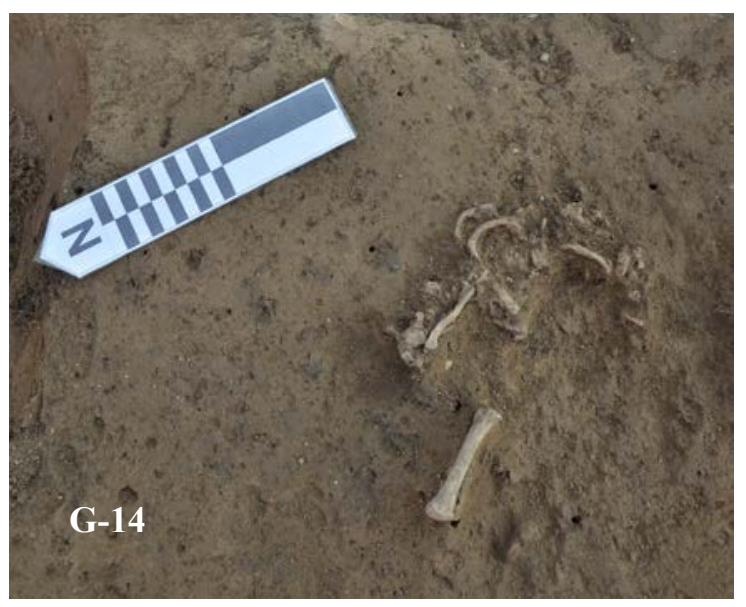

Grave G-16 (77.35)

Grave with a construction made of bricks and tegulae, approximately oriented along a northeast/south-west axis. The construction, with dimensions of $0.50 \times 0.30 \times 0.20 \mathrm{~m}$, is formed by fragmented bricks and tegulae laid sideways. The longer sides of the tomb consist of two fragmented bricks/tegulae each, while the lateral, southern side, consists of one fragmented brick. The floor of the grave consists of two fragmented, horizontally laid tegulae. The cover of the grave is missing, as well as the northern side of the tomb.

It is a grave of a new-born, laid on the back, with arms beside the body; one leg was bent at the knee, the lower leg is higher than the rest of the body, and the femur is placed vertically (proba-

\section{Grave G-17 (79.23/79.15)}

Grave with a construction made of bricks and tegulae, oriented along a north-east/south-west axis. The construction consists of a cover and bottom, while the sides of the grave construction do not exist. The cover, with dimensions of 1.10/1.20 x $0.30 / 0.50 \mathrm{~m}$, consists of a brick, large fragmented tegula and large fragments of tegulae and bricks, irregularly laid into two to four rows. Under the first layer of the cover, on the northern side of the grave, several different animal bones were discovered..$^{10}$ The bottom, with dimensions of $0.80 \mathrm{x}$

10 The bones discovered comprehended those of cattle, sheep and dog, as well as a bone of a fish from the sturgeon family. A fragment of a human bone was also discovered
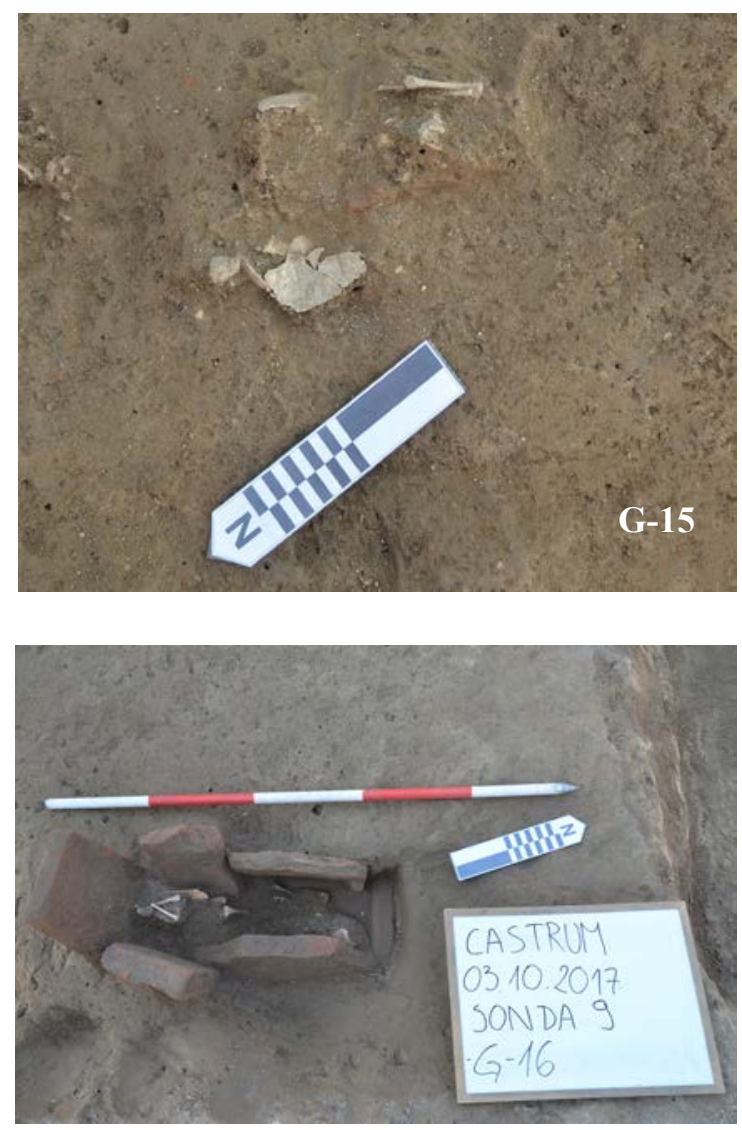

bly as a consequence of animal activity). The preserved length of the skeleton is $40 \mathrm{~cm}$. There were no goods in the grave.

* In the northern part, there was a large animal bone (scapula) across the grave, and another animal bone next to the feet of the deceased.

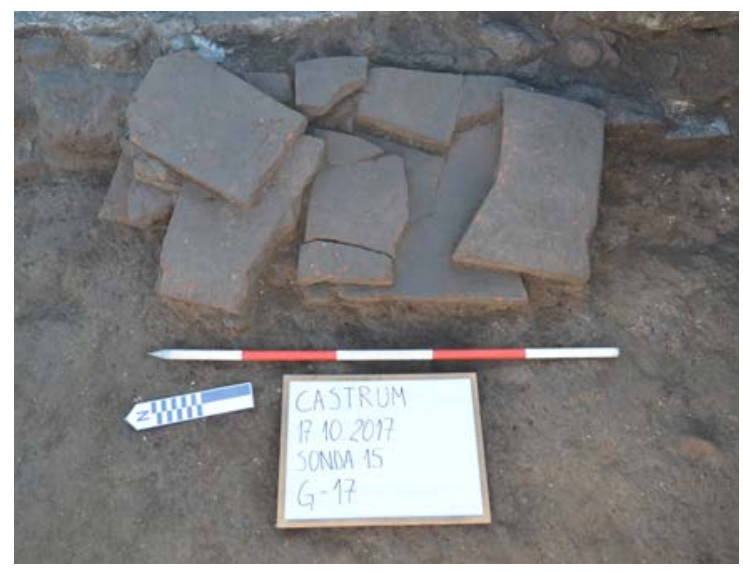


$0.28 \mathrm{~m}$, consists of two horizontally placed bricks.

It is a grave of a child aged between two and four, buried in a stretched position, with hands placed on the pelvis. The skeleton is well preserved, although the calotte of the skull is fragmented, and certain bones are missing. The preserved length of the skeleton is $0.72 \mathrm{~m}$.

There were no goods in the grave.

\section{Grave G-18 (78.58)}

Grave with a construction made of bricks, oriented along a north-west/south-east axis. The construction, with dimensions of $0.40 \times 0.30 \times 15 \mathrm{~m}$, is formed by a tomb made of sideways laid bricks, out of which only one fragmented brick was saved on each of the lateral sides, as well as one on the western front edge.

It is a grave of a new-born, buried in a stretched position. Only part of the skull, and bones of the arms have been preserved in situ (the preserved length is $0.25 \mathrm{~m}$ ), while a smaller number of bones had been dislocated.

There were no goods in the grave.

\section{Grave G-19 (78.36)}

Grave with a construction made of bricks and tegulae, oriented along a north-south axis, with a deviation of the northern part towards the east. The construction, with dimensions of $0.70 \times 0.45 \mathrm{~m}$, is formed by a tomb with sideways laid bricks, out of which only one fragmented brick was preserved on each of the shorter, lateral sides. The cover of the grave consists of two bricks placed aslant, one of them with a stamp: LEGVIICLRENO/TEMPCONCORDVC. ${ }^{11}$ Over them, frag-

among the animal remains, which could be linked to the buried individual. We would like to thank Dr. Sonja Vuković, from the Faculty of Philosophy in Belgrade, for the analysis of the archaeozoological remains.

11 The solution for this stamp would be: Leg(io) VII Cl(audia) RENO (vata/vatum) TEMP (erante/ore) CONCOR(di) DUC(is). Up until now, 31 finds of bricks with this stamp have been discovered, all in the area of Viminacium; they are linked to the reorganisation of the legion and the restoration of the fort during the First Tetrarchy (von Premerštajn, Vulić 1903: 55, n. 78; Mirković, 2015: 122; oral information by $\mathrm{Lj}$. Jevtović). Considering the
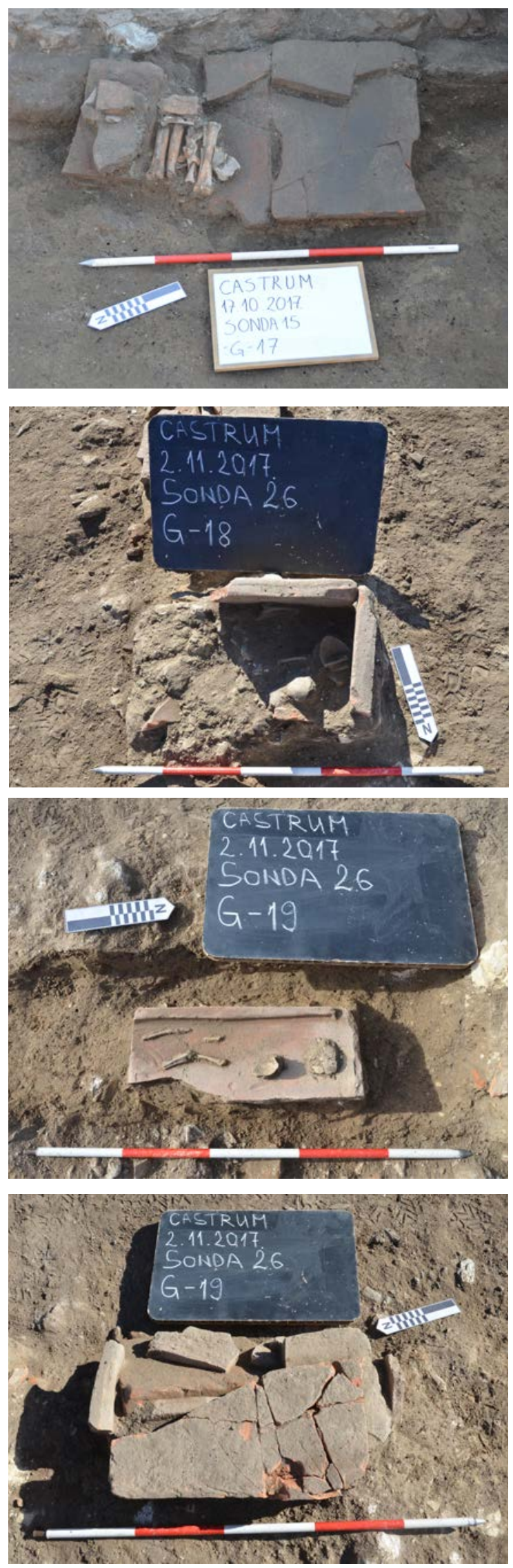
ments of bricks and a larger piece of green stone were irregularly placed. The bottom of the grave consists of a horizontally placed fragmented tegula with dimensions of $0.50 \times 0.20 \mathrm{~m}$.

It is a grave of a new-born, buried in a stretched position. Only part of the skull, and bones of the legs have been preserved in situ, while a smaller number of bones had been dislocated. The preserved length of the skeleton is $0.43 \mathrm{~m}$.

There were no goods in the grave.

\section{Grave G-20 (77.09)}

Grave of a freely buried individual, oriented along a east-west axis, with a deviation of the eastern part towards the south.

It was a partially demolished grave of a male individual, aged 20-25. The deceased was laid on the back, and on the basis of the preserved part of the skeleton, it can be assumed that he was buried in a stretched position. His head was laid on the right cheek, and turned towards the north. Of all the bones, a part of the skull, ribs, part of the pelvis, left forearm with the hand and a part of the left femur were preserved in situ. The preserved length of the skeleton is $1.05 \mathrm{~m}$.

There were no goods in the grave.

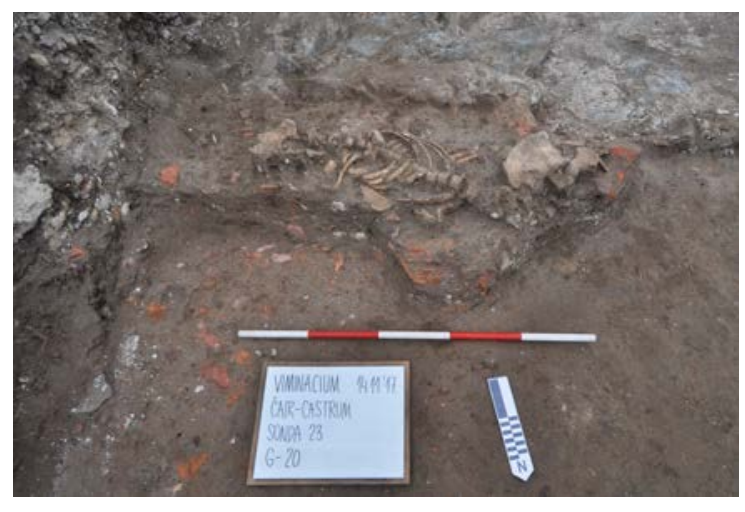

fact that the brick was most probably in secondary use, it cannot be used for dating.

We would like to thank our colleague Lj. Jevtović for the useful information and help in the interpretation of the stamp.

\section{Grave G-21 (77.90)}

Grave with a construction made of bricks and tegulae, oriented along an east-west axis, with a deviation of the western part towards the north. The construction, with dimensions of $0.60 \times 0.35$ $\mathrm{x} 0.20 \mathrm{~m}$, is formed by a tomb with sideways laid fragmented tegulae. The bottom consists of one whole and one fragmented horizontally placed brick. The cover and the southern, lateral side of the construction, are missing.

It is a grave of a new-born, buried in a stretched position, on the back, with hands on the stomach. Most of the skeleton was preserved in situ, while the bones of the chest had been dislocated, and certain bones of the hands and feet are missing. The preserved length of the skeleton is $0.50 \mathrm{~m}$. There were no goods in the grave.

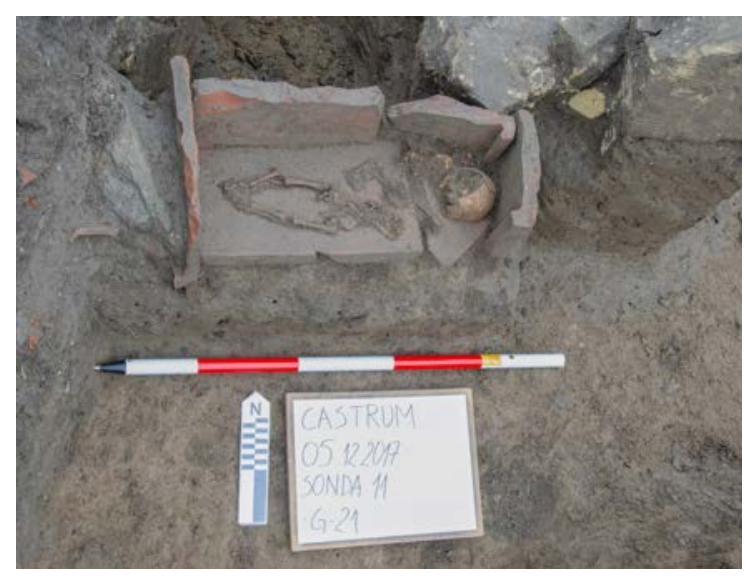




\section{Grave G-22 (77.85)}

Grave with a construction made of bricks and tegulae, oriented along a north-east/south-west axis, with a deviation of the north-eastern part towards the west. The construction, with dimensions of $1.35 \times 0.45 \times 0.37 \mathrm{~m}$, is formed by a tomb made of, sideways, longitudinally laid bricks. The shorter sides of the tomb, the northern and the southern one, are missing. The cover of the construction consists of two whole tegulae, with several fragments of bricks and tegulae over it, unevenly placed. The grave did not have a floor, the deceased was placed directly onto a layer of earth instead.

It is a grave of an adult individual, female, buried in a stretched position, on her back, with hands on the stomach and legs slightly bent at the knees, leaning towards the right side of the grave. Most of the skeleton was discovered in situ, and the bones were well preserved. The preserved length of the skeleton is $1.30 \mathrm{~m}$.

There were no goods in the grave.

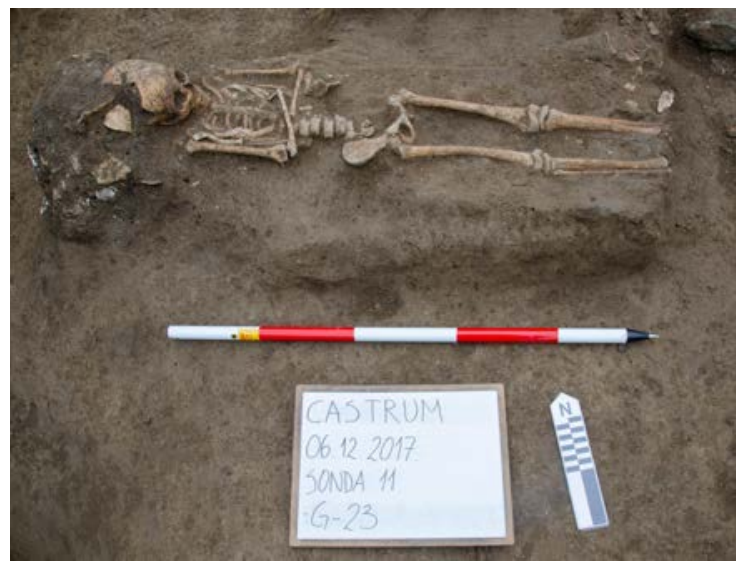

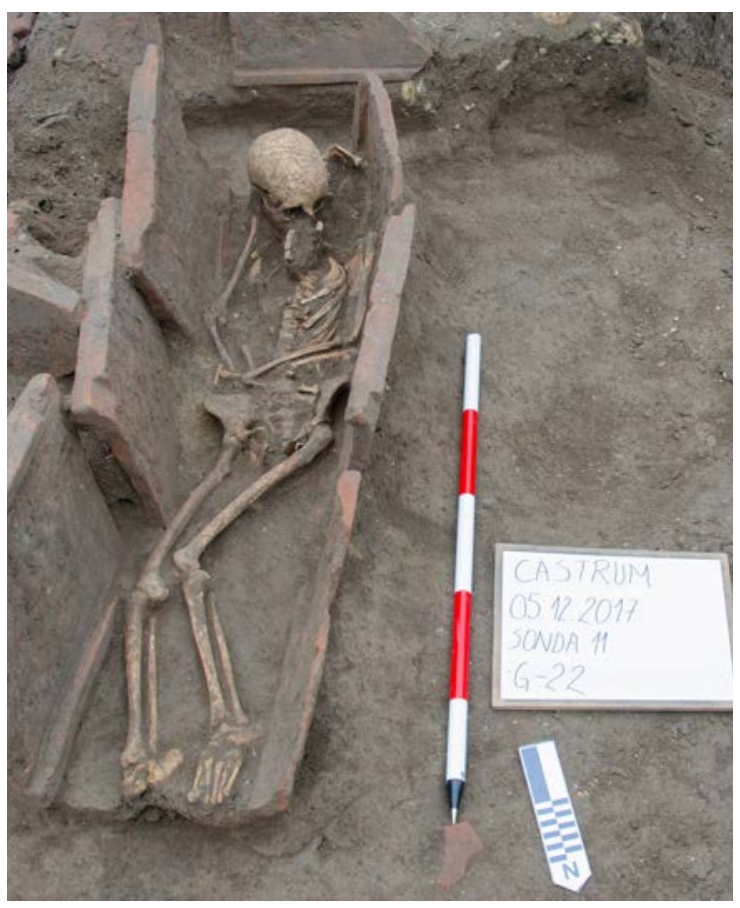

Grave G-23 (77.92)

Grave with a construction made of tegulae, oriented along a west-east axis, with a deviation of the western part towards the north. The construction, with dimensions of $0.85 \times 0.40 \times 0.35 \mathrm{~m}$, is formed by a cover of whole and fragmented tegulae, placed in the form of a double pitched roof. The construction was damaged in the western part, where a part of the cover is missing, hence, the length of the entire grave would have been approximately 1.30 $\mathrm{m}$. The shorter sides have not been discovered, and nor has the bottom of the construction - the deceased was laid directly onto the earth, dug into a layer of dark yellowish, almost sterile soil.

It is a grave of a female child, aged between 7 and 11, buried in a stretched position, on the back, with hands crossed on the chest. The bones are very well preserved, and the skeleton is almost entirely articulated. The preserved length of the skeleton is $1.13 \mathrm{~m}$.

A bronze ring was discovered on the right hand of the deceased. 


\section{Grave G-24 (77.60)}

Grave of a freely buried individual, oriented along a south-west/north-east axis, with a deviation of the north-western part towards the north.

It was a partially damaged grave of a new-born. The deceased was buried in a layer of dark yellowish, almost completely sterile clay soil. The skeleton is poorly preserved - most of the bones had been dislocated, and on the basis of the bones discovered in situ (fragments of the skull, ribs, and long bones of the legs), it can be assumed that the deceased was in a stretched position, on the back. The preserved length of the skeleton is $0.40 \mathrm{~m}$. There were no goods in the grave.

\section{Grave G-25 (77.49)}

Grave of a freely buried individual, oriented along a north-south axis, with a deviation of the northern part towards the east.

It was a partially damaged grave of a new-born, buried in a stretched position. The deceased was buried in a layer of dark yellow virgin soil. The skeleton is poorly preserved, with a large number of bones dislocated. The preserved length of the skeleton is $0.35 \mathrm{~m}$.

There were no goods in the grave.

\section{Grave G-26 (77.88)}

Grave with a construction made of tegulae, oriented along a north-west/south-east axis, with a deviation of the north-western part towards the south. The construction, with dimensions of $0.30 \times 0.20$ x $0.20 \mathrm{~m}$, is formed by two fragmented sideways laid tegulae, representing the lateral sides. The grave most probably had a cover in the form of a horizontally placed fragmented tegula, which was removed before the unit was recognised as being a grave. The shorter sides have not been discovered, and neither was the bottom of the construction the deceased was laid directly onto the earth.

It was a partially damaged grave of a new-born. On the basis of the bones that remained articulated (some of the bones of the chest, bones of the left arm, and long bones of the legs), it can
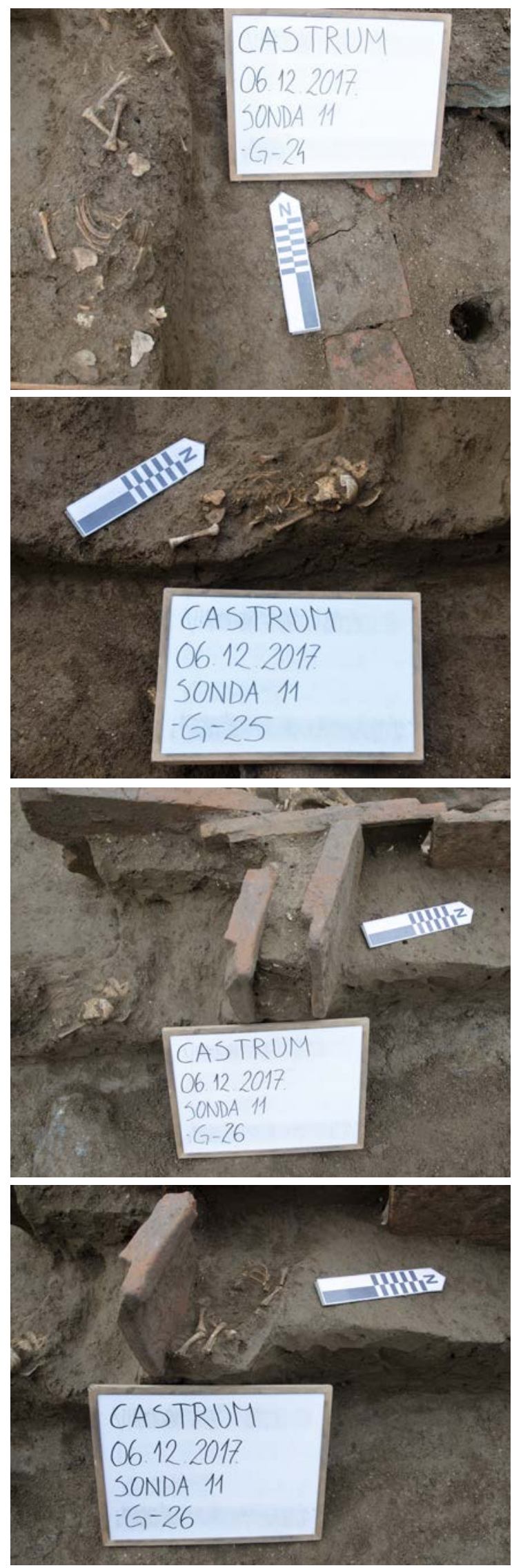
be assumed that the deceased was in a stretched position, on the back. The preserved length of the skeleton is $0.27 \mathrm{~m}$.

There were no goods in the grave.

\section{Grave G-27 (78.15)}

Grave with a construction made of tegulae, approximately oriented along a north-east/southwest axis. The construction, with dimensions of $0.58 \times 0.43 \times 0.36 \mathrm{~m}$, is formed of two tegulae in the form of a double gabled roof, with lateral sides of fragmented sideways laid tegulae and the bottom consisting of one horizontally placed tegula. The outer sides of the grave were fortified by fragments of tegulae and smaller pieces of schist. On one of the tegulae from the cover, a damaged stamp LEG[...] can be discerned.

It is a grave of a child in the first months of life, buried in a stretched position, on the back, with hands on the pelvis. Of all the bones, certain long bones of the extremities, as well as a part of the pelvis, were preserved in situ, while most of the remaining bones had been dislocated. The preserved length of the skeleton is $40 \mathrm{~cm}$.

There were no goods in the grave.

\section{Grave G-28 (78.15)}

Grave with a construction made of bricks and tegulae, approximately oriented along a north-east/ south-west axis. The construction, with dimensions of $0.70 \times 0.33 \times 0.30 \mathrm{~m}$, is formed by a cover made of two tegulae (in the form of a double pitched roof), lateral sides made of fragmented sideways laid tegulae and bottom made of one horizontally laid tegula. The outer sides of the grave were supported by fragments of tegulae.

It is a grave of a child aged up to six months. The bones of the deceased are dislocated, hence, the position cannot be determined. In the central part of the grave, there was a larger concentration of bones on a surface with dimensions of $0.25 \times 0.10 \mathrm{~m}$. There were no goods in the grave.
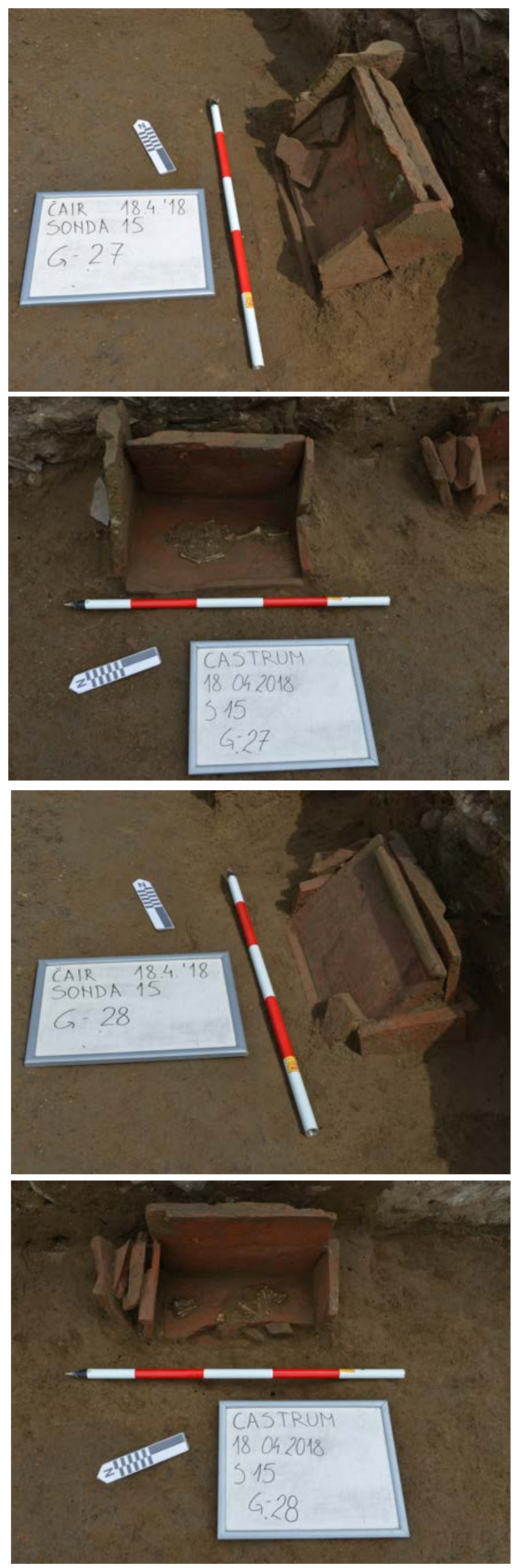


\section{Grave G-29 (77.50)}

Grave with a construction made of bricks and tegulae, approximately oriented along a north-west/ south-east axis. The construction, with dimensions of $1.70 \times 0.54 \times 0.40 \mathrm{~m}$, is formed by a tomb made of whole and fragmented sideways laid tegulae, with a bottom made of horizontally laid tegulae and bricks. The western lateral side is supported by a fragment of a tegula, while the eastern side is missing - the grave is leaning onto the virgin soil under the ramparts. The cover consists of horizontally laid tegulae and one brick, and a part of the cover is missing in the eastern half of the grave. It was a tomb of a female individual, aged ca 20 , laid on her back, with the right arm over the pelvis, and the left arm stretched along the body. Most of the skeleton was preserved in situ, and the bones are in good condition, except for a part of the pelvis and a part of the right arm and hand, which had been dislocated, possibly due to animal activity. The preserved length of the skeleton is $1.56 \mathrm{~m}$.

Two pieces of poorly preserved coins from the $4^{\text {th }}$ century were discovered in the grave (one of which was dated to the sixth decade of the 4th century), as well as a polyhedral bead made of green glass.

\section{Grave G-30 (77.45)}

Grave with a construction made of bricks, approximately oriented along a south-west/north-east axis. The construction, with dimensions of $0.84 \mathrm{x}$ $0.31 \mathrm{~m}$, is formed by a tomb made of whole and fragmented sideways laid bricks, with a bottom made of one larger piece of green schist. The cover consists of two horizontally laid bricks.

It is a grave of a child in the first months of life, buried in a stretched position, on the back, with hands on the stomach. The fragmented skull, long bones of the legs and the left hand were preserved in situ, while most of the chest, right hand, pelvis and the right femur are missing. The preserved length of the skeleton is $46 \mathrm{~cm}$.

There were no goods in the grave.
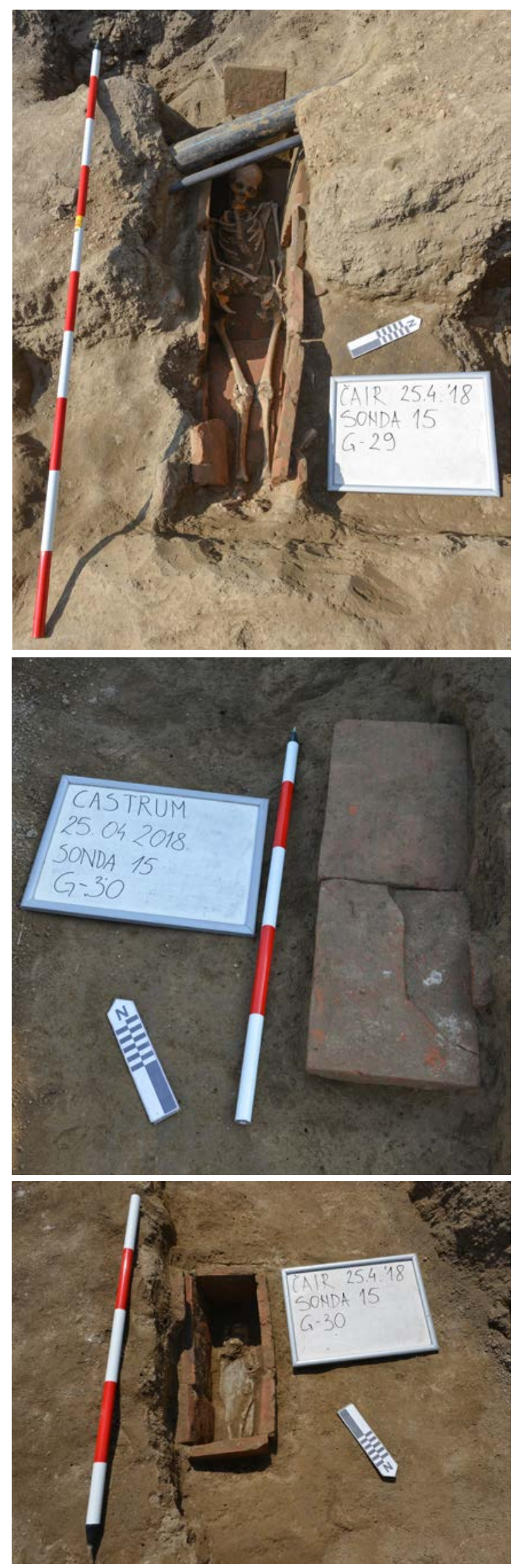


\section{Grave G-31 (77.06)}

Grave with a construction made of tegulae, approximately oriented along a north-west/southeast axis; the western side of the grave is partially demolished. The construction, with dimensions of $1.83 \times 0.49 \times 0.35 \mathrm{~m}$, is formed by a tomb made of sideways laid tegulae; the eastern side is made of two tegulae that form a sharp angle. The sides of the tomb were fortified on the outside, and in places, with smaller pieces or limestone and fragments of tegulae. The cover was formed by horizontally laid tegulae, of which only one was preserved in the eastern part, while several more fragments of the cover collapsed into the inner part of the grave. The bottom consists of two whole and several fragmented horizontally laid tegulae.

It is a grave of an adult, of undetermined sex, buried in a stretched position, on the back. The right half of the pelvis, long bones of both legs, as well as both feet, were preserved in situ. More dislocated bones were discovered in the western part and the infill of the grave. The length of the surface covered with bones is $1.40 \mathrm{~m}$, and the preserved length of the skeleton is $0.96 \mathrm{~m}$.

There were no goods in the grave.

\section{Grave G-32 (76.57)}

Grave with a construction made of bricks and tegulae, oriented along a north-west/south-east axis. The construction, with dimensions of 0.60 x $0.28 \mathrm{~m}$, is formed by sideways laid whole and fragmented tegulae, while the bottom was made of fragments of tegulae. The partially demolished construction was covered with a whole brick, which collapsed into the grave, so the bones of the skeleton were mostly smashed.

It is a grave of a new-born. The skeleton is poorly preserved, hence, it was not possible to determine the position of the deceased.

There were no goods in the grave.
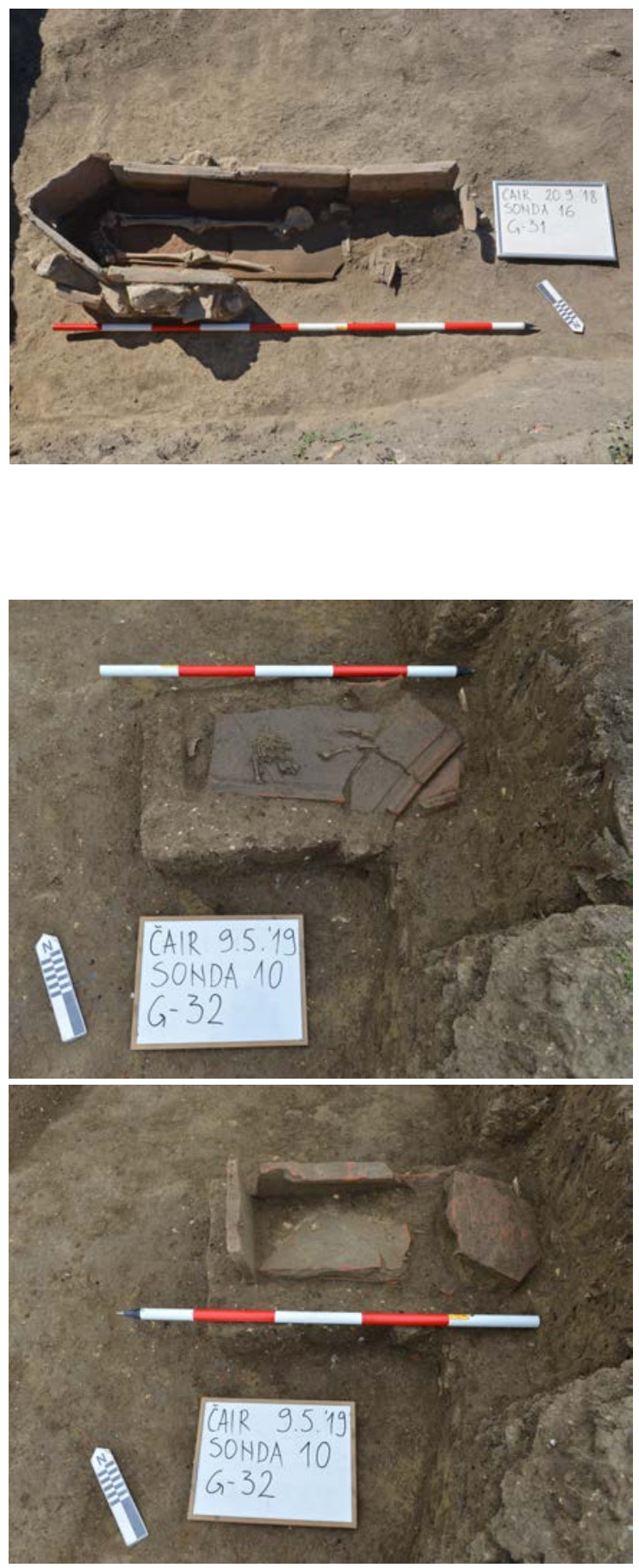


\section{Grave G-33 (76.50/76.47/76.38)}

Grave with a construction made of tegulae, oriented along a north-west/south-east axis. The construction, with dimensions of $1.30 \times 0.42 / 0.28 \mathrm{~m}$, is formed by a tomb made of sideways laid whole and fragmented tegulae. The cover is formed by three transversely placed tegulae, while the bottom has not been discovered.

It is a grave of a child, in which three individuals were buried. One individual, aged between 5 and 9, was laid on the back, the second, aged between 8 and 13, was laid on the side, with the head turned towards the south; the third individual was female, aged between 7 and 11, and, on the basis of the position, we can assume that she was also laid on the back. The bones of all three individuals are well preserved.

There were no goods in the grave.

\section{Grave G-34 (76.34/76.23)}

Grave with a construction made of tegulae, oriented along a north-west/south-east axis. The construction, with dimensions of $0.86 \times 0.37 \mathrm{~m}$, is formed by a tomb made of sideways laid tegulae; on the southern longitudinal and eastern lateral side, the tegulae have not been preserved. The cover is formed by two horizontally laid tegulae (the length of the cover is $1.10 \mathrm{~m}$, and the width $0.42 \mathrm{~m}$ ). The bottom of the grave is formed by two larger horizontally laid fragments of tegulae.

It is a grave of a child in the first year of life. The bones of the skeleton had been dislocated - only a part of the skull, left arm and several ribs were preserved in situ, hence, it was not possible to determine the position of the deceased.

There were no goods in the grave.

\section{Grave G-35 (75.90)}

Grave of a freely buried individual, oriented along a west-east axis, with a slight deviation of the western part towards south. The grave had a cover with dimensions of $1.55 \times 0.53 \mathrm{~m}$, formed by four transversely laid tegulae.

It is a grave of a female individual, aged ca 45
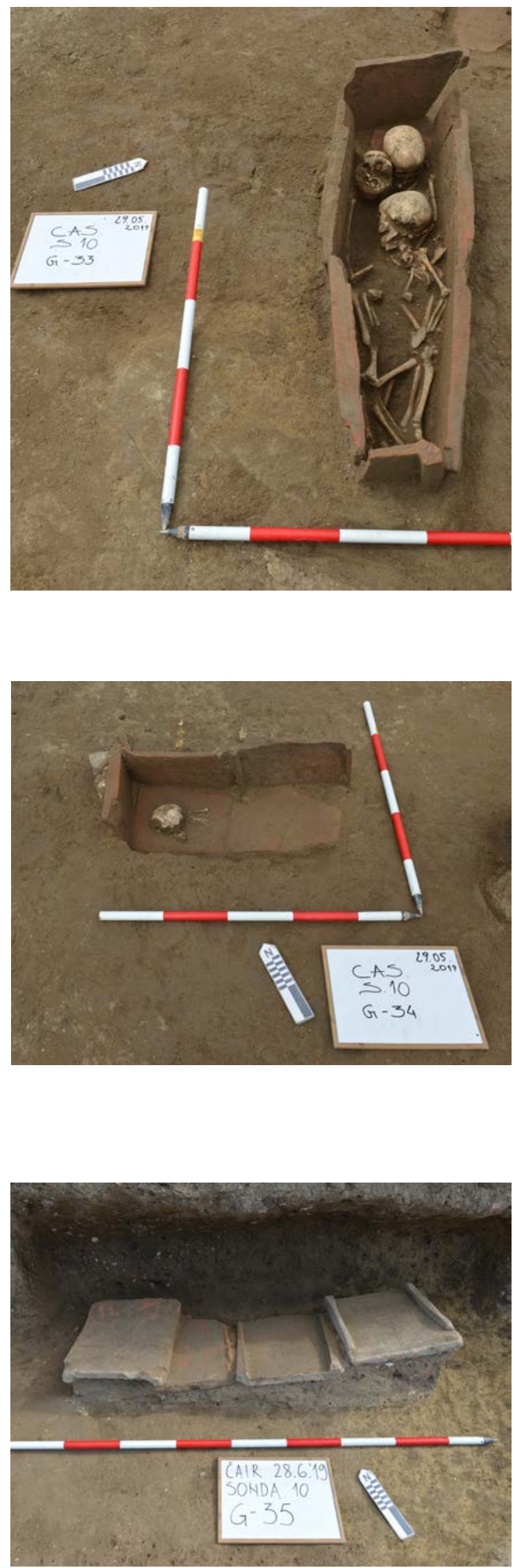
years. The deceased was laid in a stretched position, on the back, with hands on the stomach/pelvis. The skeleton is well preserved, with a length of $1.40 \mathrm{~m}$

There were no goods in the grave.

\section{Grave G-36 (77.10)}

Grave with a construction made of bricks and tegulae, oriented along a west-east axis. The construction, with dimensions of $0.55 \times 0.40 \mathrm{~m}$, is formed by a tomb made of sideways laid bricks and tegulae; the shorter, eastern side of the construction is missing. The cover is formed by larger fragments of horizontally laid tegulae, and the bottom consists of a horizontally laid brick and fragments of bricks and tegulae.

It is a grave of a new-born. The bones of the skeleton had been dislocated - only parts of the skull, several ribs and bones of both arms were preserved in situ, while other bones had been dislocated.

There were no goods in the grave.

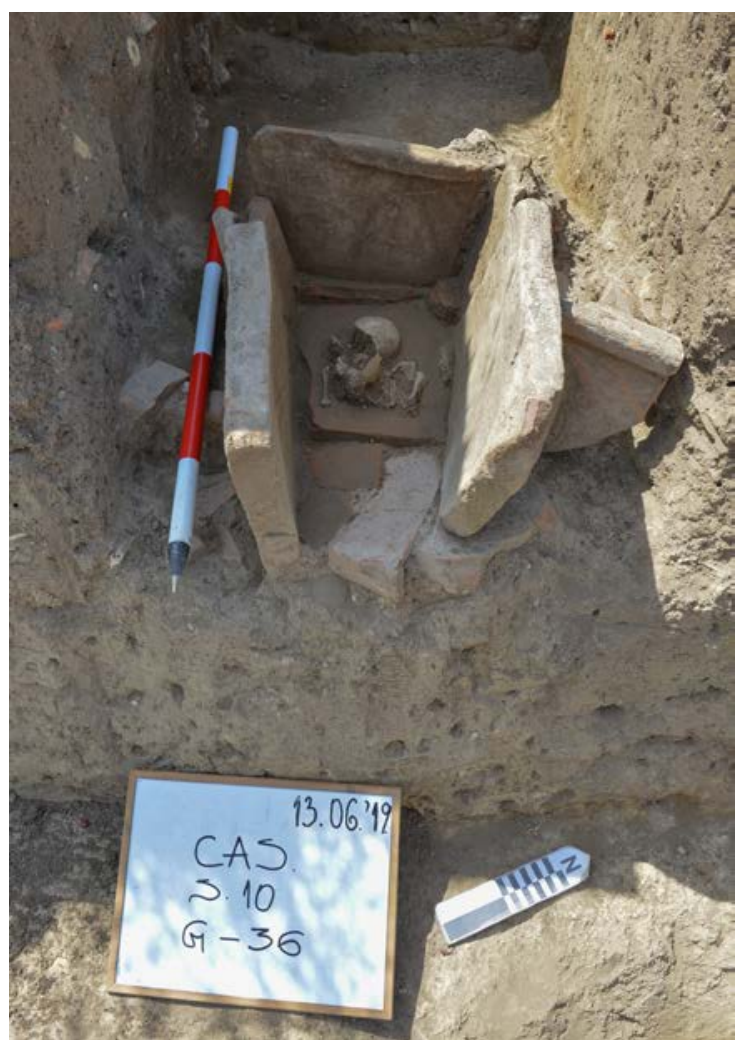

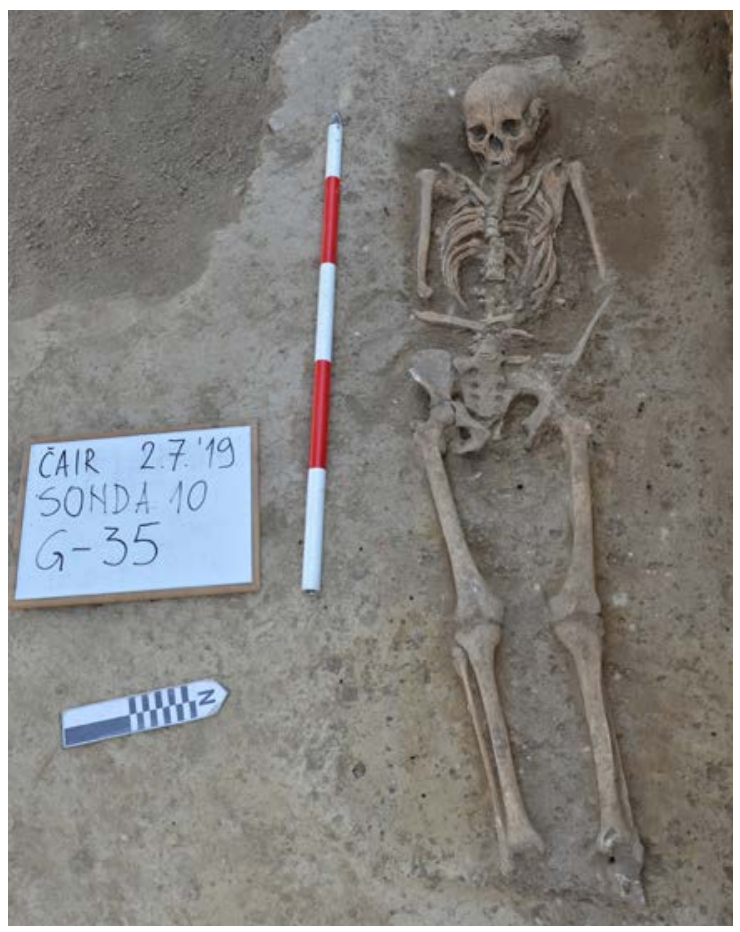

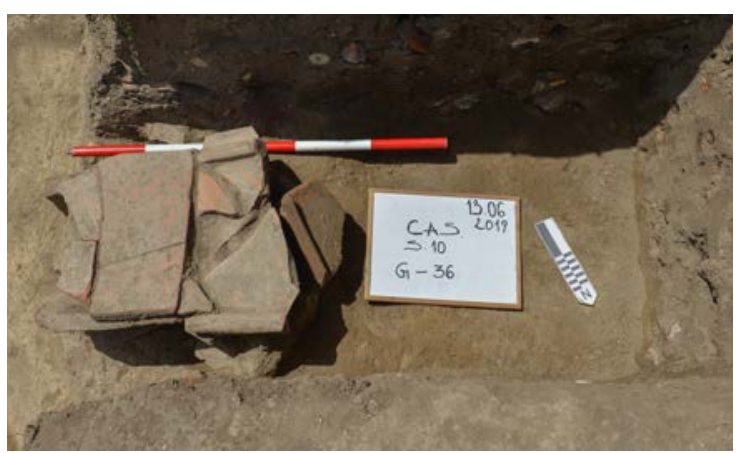

\section{BIBLIOGRAPHY}

Bogdanović, I., Jevtović, Lj., Golubović, S. 2020

Legijski logor u Viminacijumu: arheološka istraživanja severnog bedema u 2018. godini, u: S. Vitezović, M. Radišić, Đ. Obradović (ur.) Arheologija u Srbiji. Projekti Arheološkog instituta u 2018. godini, 157-172.

Данковић, И. Миловановић, Б. Марјановић, М. 2018

Од девојчице до matronae: животни ток жена на Лимесу, у: Кораћ, М., Поп-Лазић, С. (ур.) Римски лимес и градови на тлу Србије; Београд: Српска академија наука и уметности, 72-80. 
(Danković, I., Milovanović, B., Marjanović, M. Od devojčice do matronae: životni tok žena na Limesu, u: Korać M., Pop-Lazić S. (ur.), Rimski limes i gradovi na tlu Srbije, Beograd: Srpska akademija nauka i umetnosti, 72-80).

\section{Dasen, V. 2003}

Les amulettes d'enfants dans le monde gréco-romain, Latomus 62, 2: 275-289.

\section{Eckardt, H. and Williams, S. 2018}

The Sound of Magic? Bells in Roman Britain, Britannia, Volume 49: 179-210.

\section{Guido, M. 1978}

The Glass Beads of the Prehistoric and Roman Periods in Britain and Ireland, Thames and Hudson Ltd: London.

\section{Milovanović, B. 2016}

Inhumacija djece na nekropoli Više grobalja antičkog Viminacija, Vjesnik Arheološkog muzeja u Zagrebu 3, XLIX: 95-122.

\section{Mirković, M. 2015}

Rimljani na Đerdapu. Istorija i natpisi, Zaječar: Narodni muzej Zaječar, Muzej Krajine Negotin.

\section{Mrđić, N. 2009}

Topografija i urbanizacija Viminacijuma. Magistarska teza, Filozofski fakultet, Univerzitet u Beogradu, Beograd 2009.

\section{Nikolić, S. and Stojić, G. 2018}

A Review of several graves between the city and the military camp, Archaeology and Science, Vol. 14: 19-27.

\section{Nikolić et al. 2019}

Nikolić, S., Stojić, G., Marjanović, M., Bogdanović, I., Jevtović, Lj. 2019. Istraživanja na lokalitetu Čair - castrum (Viminacijum) 2017. godine, u: I. Bugarski, N. Gavrilović Vitas, V. Filipović (ur.) Arheologija u Srbiji. Projekti Arhe- ološkog instituta u 2017. godini, Beograd 2019, 125-134.

Nikolić, S., Stojić, G., Marjanović, M. 2020

Legijski logor u Viminacijumu: arheološka istraživanja zapadnog dela bedema u 2018. godini, u: S. Vitezović, M. Radišić, Đ. Obradović (ur.) $A r$ heologija u Srbiji. Projekti Arheološkog instituta u 2018. godini: Beograd 2020, 143-155.

Riha, E. 1990

Der römische Schmuck aus Augst und Kaiseraugst. Band 10, Augst: Römermuseum Augst.

Von Premerstein, A., Vulić, N. 1903

Antike Denkmäler in Serbien und Macedonien. Jahreshefte des Österreichischen Archäologischen Institutes in Wien VI, Bbl: 1-60.

\section{REZIME}

\section{NEKROPOLA UZ}

SEVEROZAPADNI UGAO VOJNOG LOGORA NA VIMINACIJUMU

\section{KLJUČNE REČI: NEKROPOLA, GROB, KASNA ANTIKA, VIMINACIUM, LEGIJSKI LOGOR, ODBRAMBENI ROV.}

Arheološka iskopavanja vojnog logora na Viminacijumu, vršena su od kraja 19. veka, a nakon nekoliko decenija pauze, nastavljena su 2002. godine. Kontinuirana istraživanja započeta 2016. godine, do 2020. godine bila su usmerena na severozapadni deo utveđenja, pretežno bedema, kula, zapadne kapije i odbrambenog rova. Utvrđene su dve osnovne faze izgradnje logora -starija, datovana u poslednje decenije I veka i mlađa, opredeljena u II vek.

Uz bedeme je otkriven i odbrambeni rov, koji je, nakon prestanka njegove odbrambene funkcije (posle treće četvrtine III veka), dobio drugačiju namenu. U njemu su izgrađeni objekati ekonomskog karaktera, kao i pet kružnih peći, koji su 
korišćeni kroz ceo IV i početak V veka.

Pored pomenutih celina, otkrivena je i kasnoantička nekropola, koja je najvećim delom bila ukopana duž spoljne strane zapadnog bedema i uz ivice rova. U okviru ove nekropole istraženo je 36 grobova, u kojima je bilo sahranjeno 37 individua. U pitanju su skeletno sahranjeni pokojnici, među kojima su najbrojnija novorođenčad i deca, dok odraslim individuama pripada svega pet grobova. Sahrane su uglavnom vršene u kovčezima od opeka i tegula, dok je slobodno ukopanih pokojnika bilo znatno manje. Grobne konstrukcije su, u većoj ili manjoj meri oštećene, a kosti skeleta uglavnom loše sačuvane i najčešće devastirane. U orijentaciji i rasporedu grobova nisu uočene pravilnosti, često su grupisani ili se nalaze na istom nivou, ali ni jedan grob ne oštećuje drugi. Većina sahrana je bez nalaza, dok je u svega pet grobova nađeno osam predmeta. Velika razlika u broju grobova uz zapadni bedem logora u odnosu na one otkrivene uz severni bedem, samo donekle može da predstavlja različit stepen istraženosti. Činjenica je da je uz severni bedem, odnosno između bedema i rova, otkriven samo jedan grob i devastirani ostaci još dve individue, dok je duž zapadnog bedema, najveći broj grobova bio skoncentrisan upravo na tom uskom prostoru. Može se pretpostaviti da su skeletni ostaci otkriveni uz severni bedem bili izuzetak, dok je prostor zapadno od zapadnog bedema $\mathrm{u}$ kasnoj antici korišćen kao nekropola. S obzirom da legijski logor, a pre svega odbrambeni rov, u kasnoj antici više nemaju istu funkciju, ne treba da iznenađuje činjenica da je ovaj prostor, iako se nalazi u neposrednoj blizini grada (intramuros?) iskorišćen za sahranjivanje. Nije nam poznato da li se ova nekropola prostirala dalje ka zapadu, ali se to može pretpostaviti na osnovu groba otktivenog zapadno od ivice rova (G-36).

Postavlja se pitanje, da li bi se sahranjivanje na ovoj nekropoli, na neki način, moglo dovesi u vezu i sa grobovima istraženim na prostoru amfiteatra, gde je otkriveno 67 grobova, među kojima je veliki broj pripadao deci. Pored njih, jugoistočno od amfiteatra, otkrivena su još četiri groba odraslih osoba, koji su, takođe, datovani u kasnoantički period-drugu polovinu IV veka.

Nesrazmerna zastupljenost dečjih sahrana, u odnosu na ukupan broj pokojnika, pored velike smrtnost novorođenčadi i dece u ovom kriznom periodu, ostaje nerazjašnjena. Cilj ovog rada je da prikaže rezultate dobijene arheološkim ispitivanjima, koji bi mogli da posluže kao osnova za dalja istraživanja logora. Očekuje se da detaljnije antropološke analize skeletnih ostataka otkriju uzrok visoke smrtnosti novorođenčadi sahranjenih na ovoj nekropoli, ali i da pruže uvid u različite aspekte života stanovništva Viminacijuma u kasnoantičkom periodu, kao što su starosna struktura, zdravstveni status i ishrana.

\section{$* * *$}

Arheologija i prirodne nauke (Archaeology and Science) is an Open Access Journal. All articles can be downloaded free of charge and used in accordance with the licence Creative Commons - Attribution-NonCommercial-NoDerivs 3.0 Serbia (https://creativecommons.org/licenses/bync-nd/3.0/rs/.

Časopis Arheologija i prirodne nauke je dostupan u režimu otvorenog pristupa. Članci objavljeni u časopisu mogu se besplatno preuzeti sa sajta i koristiti u skladu sa licencom Creative Commons - Autorstvo-Nekomercijalno-Bez prerada 3.0 Srbija (https://creativecommons.org/licenses/bync-nd/3.0/rs/. 